\title{
Solid-State Chemistry with Nonmetal Nitrides
}

\section{By Wolfgang Schnick*}

Among the nonmetal nitrides, the polymeric binary compounds $\mathrm{BN}$ and $\mathrm{Si}_{3} \mathrm{~N}_{4}$ are of particular interest for the development of materials for high-performance applications. The outstanding features of both substances are their thermal, mechanical, and chemical stability, coupled with their low density. Because of their extremely low reactivity, boron and silicon nitride are hardly ever used as starting materials for the preparation of ternary nitrides, but are used primarily in the manufacture of crucibles or other vessels or as insulation materials. The chemistry of ternary and higher nonmetal nitrides that contain electropositive elements and are thus analogous with the oxo compounds such as borates, silicates, phosphates, or sulfates was neglected for many years. Starting from the recent successful preparation of pure $\mathrm{P}_{3} \mathrm{~N}_{5}$, a further binary nonmetal nitride which shows similarities with $\mathrm{Si}_{3} \mathrm{~N}_{4}$ with regard to both its structure and properties, this review deals systematically with the solid-state chemistry of ternary and higher phosphorus(v) nitrides and the relationship between the various types of structure found in this class of substance and the resulting properties and possible applications. From the point of view of preparative solid-state chemistry the syntheses, structures, and properties of the binary nonmetal nitrides $B N, \mathrm{Si}_{3} \mathrm{~N}_{4}$, and $\mathrm{P}_{3} \mathrm{~N}_{5}$ will be compared and contrasted. The chemistry of the phosphorus(v) nitrides leads us to expect that other nonmetals such as boron, silicon, sulfur, and carbon will also participate in a rich nitride chemistry, as initial reports indeed indicate.

\section{Introduction}

Nitrogen, the main component of the atmosphere, is omnipresent. The lightest element in the fifth main group plays an important role in chemical compounds, in particular in the oxidation states $\mathrm{V}$ and III $\left(\mathrm{NO}_{3}^{-}\right.$and $\mathrm{NO}_{2}^{-}$, respectively) as well as $-\mathrm{III}\left(\mathrm{NH}_{3},-\mathrm{NH}_{2},-\mathrm{NH}-\right.$, and $\left.-\mathrm{N}-\right)$. The oxidation state of nitrogen in the nitrides is also - III; only a few hundred nitrides have so far been characterized, although for example the neighboring element oxygen has been shown to form more than ten thousand oxides. In spite of this relatively small number, the nitrides include some extremely useful compounds: silicon nitride, $\mathrm{Si}_{3} \mathrm{~N}_{4}$, has become an important nonoxidic material, whose applications range from ceramic turbochargers to integrated semiconductor modules. ${ }^{[1,2]}$ Because of its unusually high thermal conductivity $\left(285 \mathrm{Wm}^{-1} \mathrm{~K}^{-1[3]}\right)$, aluminum nitride is predestined for use as a substrate material in semiconductor manufacture. Boron nitride is used as a high-temperature crucible material, as a lubricant (hexagonal $(h)-\mathrm{BN}$ ), and in the abrasives sector (cubic (c)-BN). In recent years $h$-BN has also become increasingly important in the manufacture of composite materials.

The extreme stability of the substances, which are used as high-performance ceramics, is due in part to the strengths of the bonds joining the constituent elements; a second important factor is the presence of highly crosslinked structures in the solid state. When the electronegativity difference is only small, heteronuclear bonds with a high degree of covalent character are formed. The high chemical, thermal, and mechanical stability of nitridic materials such as silicon nitride or boron nitride results from the interplay of these two fac-

\footnotetext{
[*] Prof. Dr. W. Schnick

Laboratorium für Anorganische Chemie der Universität

Postfach 101251, D-W-8580 Bayreuth (FRG)

Telefax: Int. code (921)55-2535
}

tors: extremely strong bonds between the elements and the presence of highly crosslinked covalent structures.

Besides these two criteria, the extremely high bond energy of $\mathrm{N}_{2}\left(941 \mathrm{~kJ} \mathrm{~mol}^{-1}\right)$ as a possible decomposition product of the nitrogen compounds is also of importance when discussing the thermal stability of nitridic materials. Compared with the corresponding oxides, the thermal dissociation of many nitrides with evolution of $\mathrm{N}_{2}$ (for the oxides $\mathrm{O}_{2}$, bond energy: $499 \mathrm{~kJ} \mathrm{~mol}^{-1}$ ) occurs at much lower temperatures. Thus, the elimination of $\mathrm{N}_{2}$ from $\mathrm{Si}_{3} \mathrm{~N}_{4}$ occurs at atmospheric pressure at about $1900^{\circ} \mathrm{C}$, while $\mathrm{SiO}_{2}$ can be heated to over $2000^{\circ} \mathrm{C}$ without any noticeable decomposition. Aluminum nitride decomposes above about $1800^{\circ} \mathrm{C}$, while the extrapolated boiling point of $\mathrm{Al}_{2} \mathrm{O}_{3}$ is about $3000^{\circ} \mathrm{C}$.

The affinity of most elements for oxygen is larger than that for nitrogen, thus the bond energies for element-oxygen bonds are generally higher than those of the corresponding element-nitrogen bonds (single bond energies: $\mathrm{Si}-\mathrm{O}=444$, $\mathrm{Si}-\mathrm{N}=335 ; \mathrm{P}-\mathrm{O}=407, \mathrm{P}-\mathrm{N}=290 \mathrm{~kJ} \mathrm{~mol}^{-1[4]}$ ). Similarly the bond enthalpies of the oxides are significantly higher than those of the corresponding nitrides $\left(\Delta H_{\mathrm{f}}^{0}\left(\mathrm{SiO}_{2}\right)=\right.$ $-911,1 /{ }_{3}\left[\Delta H_{f}^{0}\left(\mathrm{Si}_{3} \mathrm{~N}_{4}\right)\right]=-248 ; 1 /{ }_{2}\left[\Delta H_{f}^{0}\left(\mathrm{~B}_{2} \mathrm{O}_{3}\right)\right]=-637$, $\Delta H_{\mathrm{f}}^{0}(\mathrm{BN})=-254 ; 1 / 2\left[\Delta H_{\mathrm{f}}^{0}\left(\mathrm{Al}_{2} \mathrm{O}_{3}\right)\right]=-838, \Delta H_{\mathrm{f}}^{0}(\mathrm{AIN})=$ $\left.-318 \mathrm{~kJ} \mathrm{~mol}^{-1[5]}\right)$, although a quantitative comparison is difficult because of their differing compositions.

The formation of oxides is thus an important side reaction in the syntheses of nitrides. Thus, the preparation of nitrides in a pure state requires the complete exclusion of oxygen and water. This precondition has certainly previously piayed an important role in hindering a detailed investigation of nitrides.

Among the theoretically possible binary main group element nitrides with nitrogen in the oxidation state - III and the electropositive elements in the maximum oxidation state corresponding to their group number, many are either nonexistent or have until now not been obtained in a pure 
and well-defined form because of their low stability (Fig. 1). $\mathrm{Li}_{3} \mathrm{~N}$ exhibits an unusually high tendency for formation; the reaction between lithium metal and molecular nitrogen starts at room temperature and atmospheric pressure without any additional activation. In contrast, there is no reliable evidence for the existence and stability of analogous compounds of the heavier alkali metals. Apparently in the nitrides $\mathrm{M}_{3} \mathrm{~N}(\mathrm{M}=\mathrm{Na}, \mathrm{K}, \mathrm{Rb}, \mathrm{Cs})$ the high formal charge of the nitride ion $\left(\mathrm{N}^{3-}\right)$ and the unfavorable molar ratio of cations to anions (3:1) make it impossible to form a stable ionic structure in which the electrostatic, coordinative, and lattice-energetic requirements of a stable solid material are fulfilled. For the alkaline earth metals, binary nitrides with the composition $\mathrm{M}_{3} \mathrm{~N}_{2}$ are, however, known for all the elements.

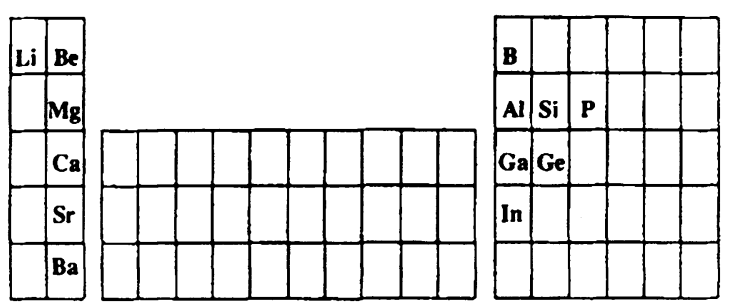

Fig. 1. Binary nitrides are only known for a fraction of the main group elements in the maximum oxidation state corresponding to their group numbers.

In contrast to the ionic structures of the nitrides of lithium and the alkaline earth metals, the decreasing electronegativities from the third group onwards lead to the formation of compounds with more covalent character (e.g. BN, AIN, $\mathrm{Si}_{3} \mathrm{~N}_{4}$ ). As the group number increases, the heavier homologues in their highest oxidation state show a clearly decreasing tendency to form stable binary nitrides: In the third main group TIN is "missing", while in the neighboring group tin and lead form no stable nitrogen compounds with the expected stoichiometry $\mathrm{M}_{3} \mathrm{~N}_{4} \cdot{ }^{[6]}$ This trend continues up to the sixth main group; here no compounds with the composition $\mathrm{M}^{\mathrm{VI}} \mathrm{N}_{2}(\mathrm{M}=\mathrm{S}, \mathrm{Se}, \mathrm{Te})$ are known. In some cases the instability of the element-nitrogen bond appears to be responsible for the nonexistence of the corresponding binary nitrides. Thus stable molecular compounds of antimony(v) and nitrogen are only formed when the basicity of the nitro- gen atoms is decreased by electron-withdrawing groups or by mesomeric effects, ${ }^{[7]}$ a requirement which is hardly realizable in the speculative compound $\mathrm{Sb}_{3} \mathrm{~N}_{5}$. In the case of other main group elements (e.g. carbon and sulfur) the reasons for the hitherto nonexistence of corresponding binary nitrides $\left(\mathrm{C}_{3} \mathrm{~N}_{4}\right.$ and $\left.\mathrm{SN}_{2}\right)$ appear to be more complex or to be due to preparative problems.

The binary nonmetal nitrides $\mathrm{BN}, \mathrm{Si}_{3} \mathrm{~N}_{4}$, and $\mathrm{P}_{3} \mathrm{~N}_{5}$ will be main subjects of the following discussion. These are the only nonmetal nitrides so far studied in detail in which the electropositive elements have the maximum possible oxidation state corresponding to their group number. The syntheses. structure, and properties of $\mathrm{BN}$ and $\mathrm{Si}_{3} \mathrm{~N}_{4}$ were described many years ago. However, both compounds had been studied because of their application in the area of high-performance materials. Because of preparative difficulties, pure phosphorus(v) nitride has only recently been obtained. Although $\mathrm{P}_{3} \mathrm{~N}_{5}$ is thermodynamically appreciably less stable than $\mathrm{BN}$ or $\mathrm{Si}_{3} \mathrm{~N}_{4}$, it has still been possible to develop a multifaceted solid-state chemistry of the phosphorus(v) nitrides. This success has provided the impetus for a further systematic search for new ternary and higher nonmetal nitrides.

\section{The Binary Nonmetal Nitrides $\mathrm{BN}, \mathrm{Si}_{3} \mathrm{~N}_{4}$, and $\mathrm{P}_{3} \mathrm{~N}_{5}$}

Binary nitrides form the basis for the syntheses of ternary or higher nonmetal nitrides containing electropositive elements. Innumerable methods for the preparation of these compounds are known; however, only a limited number of these procedures which afford pure, well-defined products can be readily carried out under laboratory conditions. Such methods must be applied when the binary nitrides are to be used in the syntheses of new compounds.

\subsection{Boron Nitride BN}

Within the family of known ceramic materials boron nitride has the lowest density $\left(\varrho=2.27 \mathrm{~g} \mathrm{~cm}^{-3}\right)$. It is colorless in the pure state and sublimes at about $2330^{\circ} \mathrm{C}$ under a nitrogen pressure of one atmosphere. ${ }^{[8]}$ Its decomposition

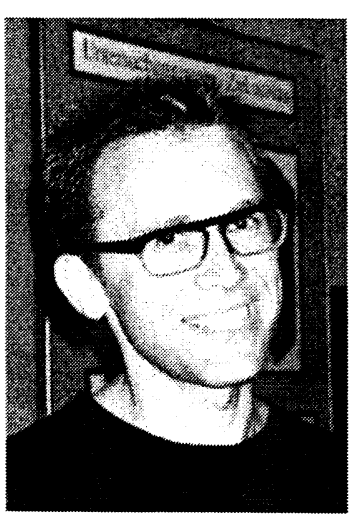

Wolfgang Schnick, born in 1957 in Hannover, studied chemistry at the Universität Hannover and received his doctorate there in 1986, having worked with Martin Jansen on alkali metal ozonides. After a postdoctoral year with Albrecht Rabenau at the Max-Planck-Institut für Festkörperforschung in Stuttgart he moved to the Universität Bonn. His habilitation in the field of inorganic chemistry was completed at the beginning of 1992. His particular interest within the area of preparative solid-state chemistry lies with the nitrides; his work is mainly concerned with their preparation and characterization, and the determination of the relationship between structures and properties. A further main area of interest involves the preparation of new types of compounds which can potentially be used as ceramic materials, ionic conductors, pigments, and catalysts. In 1989 Wolfgang Schnick was awarded the Benningsen-Foerder Prize of Nordrhein-Westfalen and in 1992 he received a Heisenberg scholarship from the Deutsche Forschungsgemeinschaft. In addition, he obtained a "Dozentenstipendium" from the Fonds der Chemischen Industrie and the Academy Prize of the Göttinger Akademie der Wissenschaften. Since 1993 he has been a Professor of Inorganic Chemistry at the Universität Bayreuth. 
vapor pressure $\left(\mathrm{N}_{2}\right)$ is $1.6 \mathrm{~Pa}$ at $1900^{\circ} \mathrm{C}$ and $573 \mathrm{~Pa}$ at $2300^{\circ} \mathrm{C},{ }^{[8]}$ while under a high nitrogen pressure $(50 \mathrm{MPa})$ boron nitride melts at about $3300^{\circ} \mathrm{C}$. ${ }^{[9]}$ Its thermodynamic data are also known. ${ }^{[8,10]}$ Boron nitride is isoelectronic with elemental carbon and, like the latter, occurs in several modifications. Hexagonal boron nitride ( $h-\mathrm{BN}, \alpha-\mathrm{BN})$ is the most stable form under normal conditions. It is analogous to graphite in that it contains planar layers of condensed sixmembered $\left[\mathrm{B}_{3} \mathrm{~N}_{3}\right]$ rings $(d(\mathrm{~B}-\mathrm{N})=145 \mathrm{pm})$. In contrast to carbon (staggered stacking) these layers are stacked directly above each other, so that the boron atoms of one layer are in direct contact with the nitrogen atoms of the neighboring layers $(d(\mathrm{~B} \cdots \mathrm{N})=333 \mathrm{pm})$. Under normal conditions the cubic $(c-\mathrm{BN}, \beta-\mathrm{BN})$ and hexagonal $(\gamma-\mathrm{BN})$ forms of boron nitride with zinc blende- and wurtzite-type structures, respectively, are metastable. ${ }^{[8]}$

Many procedures for the preparation of boron nitride have been suggested. ${ }^{[10]}$ Exceptionally pure products are obtained from the reactions of boron trichloride $\mathrm{BCl}_{3}$ with $\mathrm{NH}_{3}$ or $\mathrm{N}_{2} / \mathrm{H}_{2}$ at temperatures below $1300^{\circ} \mathrm{C}$, or by microwave discharge. ${ }^{[10,11]}$ Oxygen-free boron nitride can also be prepared from the reaction of $\mathrm{K}\left[\mathrm{BH}_{4}\right]$ with $\mathrm{NH}_{4} \mathrm{Cl}$ at temperatures up to $1050^{\circ} \mathrm{C} \cdot{ }^{[10]} \mathrm{A}$ number of industrial methods for the synthesis of boron nitride are also known, although they do not always afford pure products. These include the reactions of oxygen-containing boron compounds such as $\mathrm{B}_{2} \mathrm{O}_{3}$ or $\mathrm{B}(\mathrm{OH})_{3}$ with nitriding compounds such as urea, biuret $\left(\mathrm{NH}\left(\mathrm{CONH}_{2}\right)_{2}\right)$, dicyandiamide, or melamine and the carbothermal reduction of $\mathrm{B}_{2} \mathrm{O}_{3}$ with carbon and nitrogen at 1800 to $1900^{\circ} \mathrm{C} . .^{[10]}$ The reaction of alkaline earth metal cyanamides $\left(\mathrm{CaCN}_{2}, \mathrm{SrCN}_{2}, \mathrm{BaCN}_{2}\right)$ with boric acid $\mathrm{B}(\mathrm{OH})_{3}$ leads to mixtures of $h-\mathrm{BN}$ and the corresponding borates and cyanides. ${ }^{[10,12]}$ The direct nitridation of elemental boron can also be carried out at temperatures above $1200^{\circ} \mathrm{C}$; however, this process is of neither industrial nor preparative importance. ${ }^{[10,11]}$ Chemical vapor deposition (CVD) of boron nitride has been attempted starting from a large number of volatile, molecular boron compounds, which are particularly suitable for the formation of amorphous or crystalline thin films or fine powders. ${ }^{[8]}$ Several boron-containing polymers have also been used as precur-

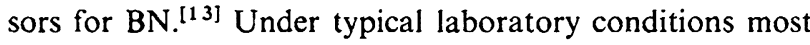
processes afford $h$-BN, which is either amorphous or has a strongly disordered crystalline structure; these can, however, be converted to a regular crystalline state by suitable thermal aftertreatment. ${ }^{[8,10]}$ The conversion of hexagonal $(\alpha-\mathrm{BN})$ to cubic $(\beta-\mathrm{BN})$ boron nitride at high pressures and temperatures is favored when $\mathrm{Li}_{3} \mathrm{BN}_{2}$ or $\mathrm{Mg}_{3} \mathrm{BN}_{3}$ are used. ${ }^{[4]}$

\subsection{Silicon Nitride $\mathrm{Si}_{3} \mathbf{N}_{4}$}

Silicon nitride is at present the most important nitridic material in the area of high-performance applications ${ }^{[15]}$ because of its great hardness (Vickers hardness $=1400$ $1700 \mathrm{MNm}^{-2}$ ), its high mechanical strength (up to about $\left.1300^{\circ} \mathrm{C}\right)$, and its low density $\left(\varrho=3.2 \mathrm{~g} \mathrm{~cm}^{-3}\right)$. Pure $\mathrm{Si}_{3} \mathrm{~N}_{4}$ decomposes above about $1900^{\circ} \mathrm{C}$. Crystalline silicon nitride exists in two polymorphous modifications $\left(\alpha-\mathrm{Si}_{3} \mathrm{~N}_{4}, \beta\right.$ $\mathrm{Si}_{3} \mathrm{~N}_{4}$ ); in both cases the structures consist of topologically similar three-dimensional networks composed of corner- sharing $\mathrm{SiN}_{4}$ tetrahedra $((d(\mathrm{Si}-\mathrm{N}) \approx 174 \mathrm{pm}$ (mean value) $)^{[16]}$ (Fig. 2). The two modifications differ only slightly in their lattice energies (difference $\approx 1.3 \%{ }^{[17]}$ ); the heat of conversion has been estimated to be about $30 \mathrm{~kJ} \mathrm{~mol}^{-1}$. $^{[1]} \mathrm{Be}-$ cause of this small difference in stability the two phases can coexist. The proportion of the $\alpha$-modification increases as the temperature at which the $\mathrm{Si}_{3} \mathrm{~N}_{4}$ is prepared decreases. The reconstructive phase transition (above $1650^{\circ} \mathrm{C}$ ) only takes place in the direction $\alpha-\mathrm{Si}_{3} \mathrm{~N}_{4} \rightarrow \beta-\mathrm{Si}_{3} \mathrm{~N}_{4}$; the reverse reaction appears to be kinetically hindered.

a
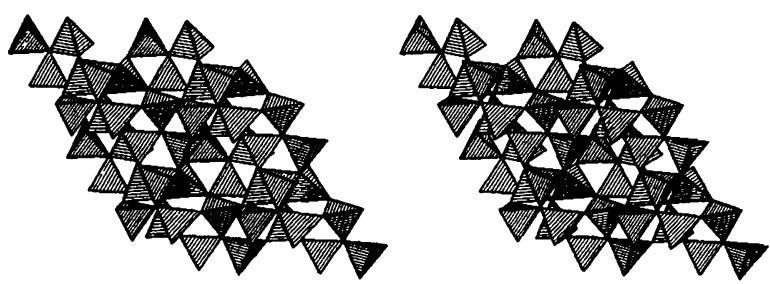

b
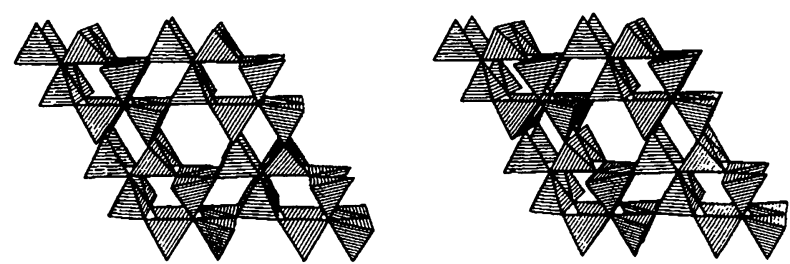

Fig. 2. Crystal structures of $x-\mathrm{Si}_{3} \mathrm{~N}_{4}$ (a) and $\beta-\mathrm{Si}_{3} \mathrm{~N}_{4}$ (b) (stereoscopic representation looking along [001]). The $\mathrm{SiN}_{4}$ tetrahedra are shown as closed polyhedra.

Three methods for the preparation of pure silicon nitride are of particular importance and are also used industrially: the direct nitridation of elemental silicon, ${ }^{[15,18-21]}$ the carbothermal reduction of silicon dioxide under a nitrogen or ammonia atmosphere, ${ }^{[15.22-26]}$ and the ammonolyses of $\mathrm{SiCl}_{4}$ or $\mathrm{SiH}_{4}{ }^{[15.27-31]}$ The ammonolysis reactions are particularly suitable for preparative purposes; they lead initially to amorphous and relatively undefined silicon diimide $\mathrm{Si}(\mathrm{NH})_{2}$, which is converted at temperatures above about $900{ }^{\circ} \mathrm{C}$ to amorphous $\mathrm{Si}_{3} \mathrm{~N}_{4}$ and above about $1300^{\circ} \mathrm{C}$ to $\alpha-\mathrm{Si}_{3} \mathrm{~N}_{4} \cdot{ }^{[15,27-29,32]}$

\subsection{Phosphorus(v) Nitride $P_{3} N_{5}$}

In contrast to the well-studied nitrides $\mathrm{BN}$ and $\mathrm{Si}_{3} \mathrm{~N}_{4}$, very little reliable information on the synthesis, structure, and properties of $\mathrm{P}_{3} \mathrm{~N}_{5}$ was available for a long time. Thus, phosphorus( $\mathrm{v})$ nitride is only mentioned in passing in Allcock's monograph on phosphorus-nitrogen compounds, ${ }^{[33]}$ while it takes up only a few lines in Corbridge's thousand-page book on phosphorus compounds. ${ }^{[34]}$

In principle it should be possible to prepare $\mathrm{P}_{3} \mathrm{~N}_{5}$ by methods analogous to those used for $\mathrm{BN}$ and $\mathrm{Si}_{3} \mathrm{~N}_{4}$. However, neither the direct nitridation of elemental phosphorus in low-pressure plasma ${ }^{[35]}$ nor the simple ammonolysis of molecular phosphorus compounds such as $\mathrm{PCl}_{5}, \mathrm{P}_{4} \mathrm{~S}_{10}$, $(\mathrm{PNCl})_{3},\left(\mathrm{PN}\left(\mathrm{NH}_{2}\right)_{2}\right)_{3}$, or $\mathrm{SP}\left(\mathrm{NH}_{2}\right)_{3}{ }^{[36-42]}$ lead to the formation of pure, crystalline, and well-defined phosphorus(v) 
nitride. Such attempts lead in fact to amorphous products that in some cases still contain chlorine, sulfur, or hydrogen; these generally have a very large surface area and cannot be characterized further. The main problem in the synthesis of pure crystalline $\mathrm{P}_{3} \mathrm{~N}_{5}$ is that this nitride is much less thermally stable than $\mathrm{BN}$ or $\mathrm{Si}_{3} \mathrm{~N}_{4}$; thus, decomposition with evolution of nitrogen occurs above about $850^{\circ} \mathrm{C}$ [Eq. (1)].

$2 \mathrm{P}_{3} \mathrm{~N}_{5} \longrightarrow 6 \mathrm{PN}+2 \mathrm{~N}_{2} \longrightarrow 3 \mathrm{P}_{2}+5 \mathrm{~N}_{2}$

Brown undefined amorphous phosphorus(III) nitride is formed in this reaction; thus, in contrast to the situation for boron or silicon nitride it is not possible to remove impurities (such as $\mathrm{H}, \mathrm{Cl}$ or $\mathrm{S}$ ) simply by raising the temperature and thereby obtaining monophasic $\mathrm{P}_{3} \mathrm{~N}_{5}$. The preparation of pure crystalline $\mathrm{P}_{3} \mathrm{~N}_{5}$ starting from molecular phosphorus compounds is thus a tightrope walk between incipient thermal decomposition and sufficient activation of the P-N bonds (cleavage and reformation) for the construction of an ordered crystalline solid via amorphous polyphosphazene intermediates. ${ }^{[43]}$ Since thermal activation alone is insufficient, the necessary $\mathrm{P}-\mathrm{N}$ bond breaking and formation must be supported by chemical means.

The ammonolysis of $\mathrm{PCl}_{5}$ or $\left(\mathrm{PNCl}_{2}\right)_{3}$ using $\mathrm{NH}_{4} \mathrm{Cl}$ rather than $\mathrm{NH}_{3}$ at temperatures below $800^{\circ} \mathrm{C}$ indeed leads to the formation of colorless, microcrystalline compact $\mathrm{P}_{3} \mathrm{~N}_{5}$ that is hydrogen- and chlorine-free [Eqs. (2), (3)]. It seems likely that the $\mathrm{HCl}$ present, which in pure form decomposes $\mathrm{P}_{3} \mathrm{~N}_{5}$ at higher temperatures with the formation of volatile products, leads to the reversible and reconstructive formation of crystalline $\mathrm{P}_{3} \mathrm{~N}_{5} \cdot{ }^{[43]}$

$\left(\mathrm{PNCl}_{2}\right)_{3}+2 \mathrm{NH}_{4} \mathrm{Cl} \stackrel{780^{\circ} \mathrm{C}, 2 \mathrm{~d}}{\longrightarrow} \mathrm{P}_{3} \mathrm{~N}_{5}+8 \mathrm{HCl}$

$3 \mathrm{PCl}_{5}+5 \mathrm{NH}_{4} \mathrm{Cl} \stackrel{780^{\circ} \mathrm{C} .2 \mathrm{~d}}{\longrightarrow} \mathrm{P}_{3} \mathrm{~N}_{5}+20 \mathrm{HCl}$

According to IR, EXAFS, ED, HRTEM, and ${ }^{15} \mathrm{~N}$ and ${ }^{31} \mathrm{P}$ solid-state MAS NMR spectroscopic studies, ${ }^{[*]}$ phosphorus(v) nitride $\mathrm{P}_{3} \mathrm{~N}_{5}$ has a three-dimensional network, consisting of corner-sharing $\mathrm{PN}_{4}$ tetrahedra $(d(\mathrm{P}-\mathrm{N})$ $=160 \mathrm{pm}) .{ }^{[43]}$ The solid, formulated as ${ }_{\infty}^{3}\left[\mathrm{P}_{3}^{[4]} \mathrm{N}_{2}^{[3]} \mathrm{N}_{3}^{[2]}\right]$, contains two types of nitrogen atom in a molar ratio of $2: 3$, which are linked to three and two phosphorus atoms, respectively. ${ }^{[4]}$ Because of a stacking disorder in $\mathrm{P}_{3} \mathrm{~N}_{5}$ demonstrated by HRTEM, ${ }^{[43]}$ it has so far not been possible to carry out a complete single-crystal X-ray structural analysis. However, recently, completely ordered single crystals of $\mathrm{P}_{3} \mathrm{~N}_{5}$ have been obtained. ${ }^{[43]}$

\section{Ternary and Higher Phosphorus(v) Nitrides}

The combination of the two elements phosphorus and nitrogen is isosteric with a corresponding combination of silicon and oxygen. This fact stimulated the systematic study of the siloxanes (typical building block: $\left.-\mathrm{R}_{2} \mathrm{Si}-\mathrm{O}-\mathrm{SiR}_{2}-\right)^{[44,45]}$ in analogy to the isosteric phosphazenes (typical building block: $-\mathrm{R}_{2} \mathrm{P}=\mathrm{N}-\mathrm{PR}_{2}=$ ). Wide-

["] EXAFS = extended X-ray absorption fine structure, ED = electron diffraction. HRTEM = high-resolution transmission electron microscopy, $\mathrm{MAS}=$ magic angle spinning. ranging systematic investigations of the chemistry of molecular $\mathrm{P}-\mathrm{N}$ compounds have led to the discovery of a very large number of well-characterized monomeric, oligomeric, and polymeric phosphazenes; these can contain diverse substituents $\mathrm{R}$ (such as $\mathrm{F}, \mathrm{Cl}, \mathrm{Br}, \mathrm{NH}_{2}, \mathrm{NR}_{2}, \mathrm{CF}_{3}, \mathrm{~N}_{3}, \mathrm{NCS}$, $\mathrm{NCO}$ ). It has proved possible not only to synthesize chainlike and cyclic phosphazenes of widely varying molecular size but also to cross-link such units to give polymeric materials with exactly tailored properties. ${ }^{[33,34,46]}$ In contrast to the phosphazenes, the siloxanes are, however, much less readily accessible; thus, the systematic investigation of this class of compounds has taken place only relatively recently. ${ }^{[44,45]}$

The situation is completely opposite in the case of the corresponding $\mathrm{Si}-\mathrm{O}$ and $\mathrm{P}-\mathrm{N}$ solid-state compounds. While a large group of preparatively readily accessible $\mathrm{Si}-\mathrm{O}$ compounds (silicates, silicon dioxide) ${ }^{[47]}$ is known which also includes a number of naturally occurring species (e.g. quartz, pyroxene, amphibole, kaolinite, pyrophillite, mica, feldspar), there were only a few indications of the possible existence of analogous P-N compounds. ${ }^{[48,49]}$ The analogy between silicon oxides (silicates) and phosphorus(v) nitrides is, however, not so close as the isostericity between molecular siloxanes and phosphazenes discussed previously, in which in each case a molar ratio of $\mathrm{Si}: \mathrm{O}=\mathrm{P}: \mathrm{N}=1: 1$ is involved. The consideration of typical silicate building blocks and the corresponding phosphorus-nitrogen isosteres shows the formal charge to be different in each case: $\mathrm{SiO}_{4}^{4-} / \mathrm{PN}_{4}^{7-}$, $\mathrm{Si}_{3} \mathrm{O}_{9}^{6-} / \mathrm{P}_{3} \mathrm{~N}_{9}^{12-}, \mathrm{SiO}_{2} / \mathrm{PN}_{2}^{-}$. When these charges are compensated in ternary compounds by cations of electropositive elements (e.g. alkali metals or alkaline earth metals), we can expect that mainly covalent $\mathrm{P}-\mathrm{N}$ substructures as well as contacts between nitrogen and the cations with clearly ionic character will be formed. Thus, in spite of their differing overall composition the phosphorus(v) nitrides should contain $\mathrm{P}-\mathrm{N}$ substructures which have isosteric analogues within the silicate family.

For a long time it proved impossible to prepare phosphorus(v) nitrides in a pure crystalline form, and no reliable information existed on the structure and properties of particular compounds. The greatest problem was that pure $\mathrm{P}_{3} \mathrm{~N}_{5}$ was not available as a starting material for the preparation of such compounds. Thus, the development of a route to well-defined phosphorus(v) nitride (see Section 2.3) was a basic precondition for the systematic study of ternary and higher phosphorus(v) nitrides containing electropositive elements.

\subsection{Alkali Metal and Alkaline Earth Metal Phosphorus(v) Nitrides}

Ternary phosphorus(v) nitrides derived from metals should be accessible from the corresponding binary nitrides. The analogy with oxo chemistry suggests that a reaction between an "acidic" nonmetal nitride $\left(\mathrm{P}_{3} \mathrm{~N}_{5}\right)$ and a "basic" metal nitride should be successful. For various reasons the quasibinary $\mathrm{Li}_{3} \mathrm{~N} / \mathrm{P}_{3} \mathrm{~N}_{5}$ system appeared to be particularly suitable for the systematic study of the ternary phosphorus(v) nitrides: Among the alkali metals only lithium forms a binary nitride with the composition $\mathrm{M}_{3} \mathrm{~N}(\mathrm{M}=\mathrm{Li}, \mathrm{Na}, \mathrm{K}$, 
$\mathrm{Rb}, \mathrm{Cs})$. Lithium nitride is readily available from its constituent elements; ${ }^{[50]}$ in addition its thermodynamic stability is sufficient to permit reactions with phosphorus(v) nitride to be carried out in the temperature range $600-850^{\circ} \mathrm{C}$.

The quasibinary $\mathrm{Li}_{3} \mathrm{~N} / \mathrm{P}_{3} \mathrm{~N}_{5}$ system has so far afforded four lithium phosphorus( $(v)$ nitrides, which have been prepared in a pure form and characterized both structurally and with respect to their properties: $\mathrm{Li}_{7} \mathrm{PN}_{4},{ }^{[51]} \mathrm{Li}_{12} \mathrm{P}_{3} \mathrm{~N}_{9},{ }^{[52.53]}$ $\mathrm{Li}_{10} \mathrm{P}_{4} \mathrm{~N}_{10},{ }^{[54]}$ and $\mathrm{LiPN}_{2}{ }^{[55]}$ can in each case be prepared in solid-state reactions between stoichiometric amounts of the binary nitrides $\mathrm{Li}_{3} \mathrm{~N}$ and $\mathrm{P}_{3} \mathrm{~N}_{5}$ [Eqs. (4)-(7)]. A crucial factor

$$
\begin{aligned}
& 7 \mathrm{Li}_{3} \mathrm{~N}+\mathrm{P}_{3} \mathrm{~N}_{5}-\frac{620 \mathrm{C} .4 \mathrm{~d}}{\text { W crucible. } \mathrm{N}_{2} \text { atm. }} 3 \mathrm{Li}_{7} \mathrm{PN}_{4} \\
& 4 \mathrm{Li}_{3} \mathrm{~N}+\mathrm{P}_{3} \mathrm{~N}_{5} \underset{\text { W crucible. } \mathrm{N}_{2} \text { atm. }}{\longrightarrow} \mathrm{Li}_{12} \mathrm{P}_{3} \mathrm{~N}_{9} \\
& 10 \mathrm{Li}_{3} \mathrm{~N}+4 \mathrm{P}_{3} \mathrm{~N}_{5} \underset{\mathrm{W} \text { crucible. } \mathrm{N}_{2} \text { atm. }}{\frac{720 \mathrm{C} .5 \mathrm{~d}}{\mathrm{C}}} 3 \mathrm{Li}_{10} \mathrm{P}_{4} \mathrm{~N}_{10} \\
& \mathrm{Li}_{3} \mathrm{~N}+\mathrm{P}_{3} \mathrm{~N}_{5}-\frac{800 \mathrm{C} .4 \mathrm{~d}}{\mathrm{~W} \text { crucible. } \mathrm{N}_{2} \text { atm. }} 3 \mathrm{LiPN}_{2}
\end{aligned}
$$

in these reactions is the choice of the crucible material, since at the temperatures used lithium nitride reacts with all the standard materials. Pure tungsten metal is particularly suitable for the crucibles for these reactions, since under the reaction conditions used the interior of the crucible is passivated by a layer of tungsten nitride, which, when all the experimental parameters (temperature, reaction time, particle size of the $\mathrm{Li}_{3} \mathrm{~N}$ used) are optimized, prevents a further attack on the crucible to give $\mathrm{Li}_{6} \mathrm{WN}_{4}$.

Besides reactions between the binary nitrides, it is also possible to react the lithium phosphorus(v) nitrides themselves with $\mathrm{Li}_{3} \mathrm{~N}$ or $\mathrm{P}_{3} \mathrm{~N}_{5}$ to obtain the corresponding ternary phases [Eqs. (8)-(11)].

$$
\begin{aligned}
& 2 \mathrm{Li}_{3} \mathrm{~N}+\mathrm{LiPN}_{2} \underset{\text { W crucible. } \mathrm{N}_{2} \text { atm. }}{\rightarrow} \mathrm{Li}_{7} \mathrm{PN}_{4} \\
& 2 \mathrm{Li}_{3} \mathrm{~N}+4 \mathrm{LiPN}_{2} \underset{\text { W crucible. } \mathrm{N}_{2} \text { atm. }}{700^{\circ} \mathrm{C} .5 \mathrm{~d}} \mathrm{Li}_{10} \mathrm{P}_{4} \mathrm{~N}_{10} \\
& 6 \mathrm{P}_{3} \mathrm{~N}_{5}+10 \mathrm{Li}_{7} \mathrm{PN}_{4}-\frac{630^{\circ} \mathrm{C} \cdot 10 \mathrm{~d}}{\text { W crucible. } \mathrm{N}_{2} \text { atm. }} 7 \mathrm{Li}_{10} \mathrm{P}_{4} \mathrm{~N}_{10} \\
& 3 \mathrm{Li}_{3} \mathrm{~N}+3 \mathrm{LiPN}_{2} \underset{\text { W crucible. }}{\stackrel{770}{\mathrm{~N}_{2} \text { atm. }}} \mathrm{Li}_{12} \mathrm{P}_{3} \mathrm{~N}_{9}
\end{aligned}
$$

The lithium phosphorus(v) nitrides are obtained from these syntheses as colorless powders or transparent single crystals. The sensitivity of the compounds towards hydrolysis increases with increasing lithium content and their thermal stability decreases. While $\mathrm{LiPN}_{2}$ is stable up to about $900^{\circ} \mathrm{C}$ and is hardly affected by moist air or water, $\mathrm{Li}_{7} \mathrm{PN}_{4}$ decomposes above $650^{\circ} \mathrm{C}$ and is hydrolyzed by water in a violent reaction. The two other ternary compounds $\mathrm{Li}_{12} \mathrm{P}_{3} \mathrm{~N}_{9}$ and $\mathrm{Li}_{10} \mathrm{P}_{4} \mathrm{~N}_{10}$ take up an intermediate position in both respects, decomposing above about $780^{\circ} \mathrm{C}$ and being somewhat sensitive towards hydrolysis.

All the lithium phosphorus(v) nitrides referred to have an ionic structure consisting of $\mathrm{Li}^{+}$ions and complex $\mathrm{P}-\mathrm{N}$ anions. The common structural features are the $\mathrm{PN}_{4}$ tetrahedra, which can be linked in different ways through common vertices: $\mathrm{Li}_{7} \mathrm{PN}_{4}$ contains "isolated" $\left[\mathrm{PN}_{4}\right]^{7-}$ ions (mean
$\mathrm{P}-\mathrm{N}$ bond length $=171 \mathrm{pm}$ ), which are isoelectronic with orthosilicate $\left[\mathrm{SiO}_{4}\right]^{4-}$ and orthophosphate $\left[\mathrm{PO}_{4}\right]^{3-}$ building blocks. In the cubic unit cell of $\mathrm{Li}_{7} \mathrm{PN}_{4}$, the complex anions are arranged in a manner analogous to the $\beta$-tungsten type (A15) (Fig. 3), while the $\mathrm{Li}^{+}$ions are tetrahedrally coordinated by the nitrogen atoms of the $\mathrm{PN}_{4}$ tetrahedra. The crystal structure of $\mathrm{Li}_{7} \mathrm{PN}_{4}$ can be considered as an anti-fluorite type. Thus, the nitrogen atoms adopt a distorted cubic close packing, in which $\mathrm{Li}^{+}$ions and phosphorus atoms occupy all the tetrahedral holes in an ordered manner. ${ }^{[51]}$
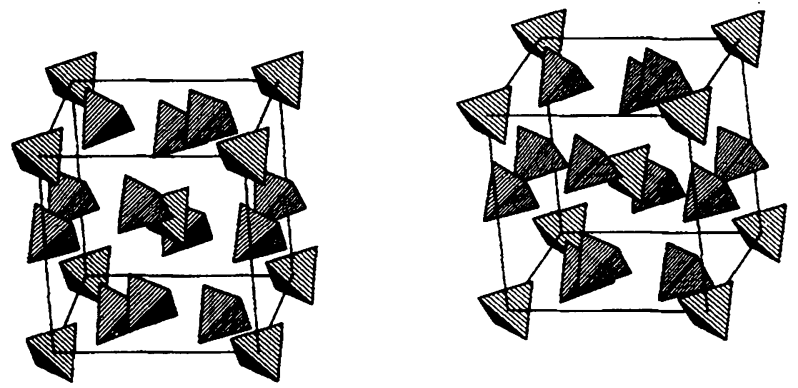

Fig. 3. Unit cell of $\mathrm{Li}_{7} \mathrm{PN}_{4}$ (stereoscopic representation). The $\mathrm{PN}_{4}$ tetrahedra are shown as closed polyhedra; for the sake of clarity the $\mathrm{Li}^{+}$ions are not shown [51].

At the quasibinary $\mathrm{Li}_{3} \mathrm{~N} / \mathrm{P}_{3} \mathrm{~N}_{5}$ intersection, $\mathrm{LiPN}_{2}$ is found as the compound with the lowest lithium content. $\mathrm{PN}_{4}$ tetrahedra are again the characteristic building blocks of the $\mathrm{P}-\mathrm{N}$ substructure. However, because of the molar ratio $P: N=1: 2$ they are not isolated but form a three-dimensional infinitely linked network ${ }_{x}^{3}\left[\mathrm{PN}_{4 / 2}^{-}\right]$, which is topologically equivalent to and isoelectronic with $\beta$-cristobalite $\left(\mathrm{SiO}_{2}\right)$ $\left(d(\mathrm{P}-\mathrm{N})=164.5(7) \mathrm{pm}, \Varangle \mathrm{P}-\mathrm{N}-\mathrm{P}=123.6(8)^{\circ[55]}\right)$. Compared with the $C 9$ type (the idealized $\beta$-cristobalite structure), LiPN ${ }_{2}$ is clearly distorted; all the $\mathrm{PN}_{4}$ tetrahedra are rotated by an angle $\varphi=34.2^{\circ}$ about their axes of inversion. According to O'Keeffe and Hyde, ${ }^{[56]}$ a distortion of this type starting from a filled variant of the C9 type $\left(\varphi=0^{\circ}\right)$ leads, by a continuous transformation, to the chalcopyrite type $\left(\varphi=45^{\circ}\right)$, a superstructural variant of zinc blende. Thus, the crystal structure of $\mathrm{LiPN}_{2}$ (Fig. 4) can also be explained on the basis of the concept of sphere packing: $\mathrm{Li}^{+}$ions and phosphorus atoms systematically occupy half of the tetrahedral holes in a distorted cubic closest packing of nitrogen atoms in an ordered manner. The $\mathrm{Li}^{+}$ions and phosphorus
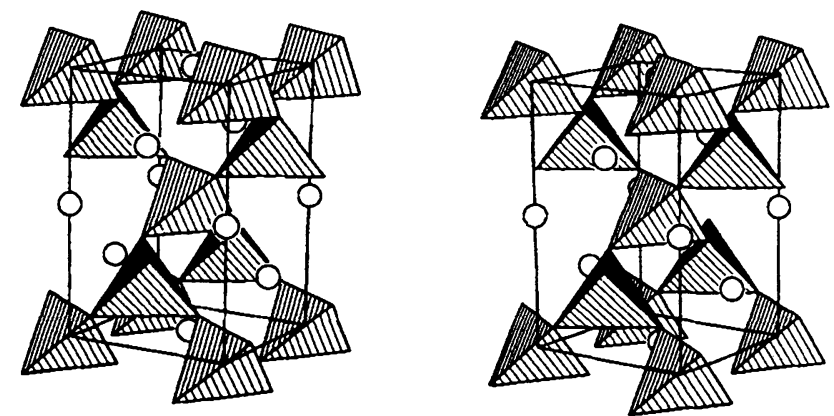

Fig. 4. Crystal structure of $\mathrm{LiPN}_{2}$ (stereoscopic representation). The $\mathrm{PN}_{4}$ tetrahedra, which are condensed at all their vertices, are shown as closed polyhedra, the $\mathrm{Li}^{+}$ions as open circles [55]. 
atoms in $\mathrm{LiPN}_{2}$ and $\mathrm{Li}_{7} \mathrm{PN}_{4}$ appear not to be influenced by the significantly different bonding situations of $\mathrm{P}$ and $\mathrm{N}$ on the one hand or of $\mathrm{Li}$ and $\mathrm{N}$ (mainly covalent and ionic, respectively), on the other; thus, it is surprising to find such extreme structural similarities.

Within the quasibinary $\mathrm{Li}_{3} \mathrm{~N} / \mathrm{P}_{3} \mathrm{~N}_{5}$ system, $\mathrm{Li}_{7} \mathrm{PN}_{4}$ and LiPN $\mathrm{N}_{2}$ are the two ternary compounds with the highest and lowest lithium content, respectively. Their anionic $\mathrm{P}-\mathrm{N}$ substructures $\left[\mathrm{PN}_{4}\right]^{7-}$ and ${ }_{x}^{3}\left[\mathrm{PN}_{4 / 2}^{-}\right]$are isosteric analogues of orthosilicate and silicon dioxide, respectively; these two $\mathrm{Si}-$ O compounds have the lowest and highest degree of condensation of $\mathrm{SiO}_{4}$ tetrahedra, respectively. In analogy with the large family of silicate structures, it appeared appropriate to search for phosphorus(v) nitrides with an intermediate degree of condensation of corner-sharing $\mathrm{PN}_{4}$ tetrahedra, which are perhaps similar to the chain or layer silicates.

Two further ternary compounds within the $\mathrm{Li}_{3} \mathrm{~N} / \mathrm{P}_{3} \mathrm{~N}_{5}$ system. $\mathrm{Li}_{4} \mathrm{PN}_{3}$ and $\mathrm{Li}_{5} \mathrm{P}_{2} \mathrm{~N}_{5}$, have both been prepared in a pure state and structurally characterized. In comparison with $\mathrm{Li}_{7} \mathrm{PN}_{4}$ and $\mathrm{LiPN}_{2}$, both of these lithium phosphorus(v) nitrides have an intermediate lithium content. We thus expected to find an intermediate degree of condensation of the corner-sharing $\mathrm{PN}_{4}$ tetrahedra. In fact $\mathrm{Li}_{4} \mathrm{PN}_{3}$, in analogy to the cyclotrisilicate $\left[\mathrm{Si}_{3} \mathrm{O}_{9}\right]^{6-}$, contains complex anions with three corner-sharing $\mathrm{PN}_{4}$ tetrahedra, ${ }^{[52.53]}$ and thus the formula for this lithium phosphorus(v) nitride is $3\left(\mathrm{Li}_{4} \mathrm{PN}_{3}\right)=\mathrm{Li}_{12} \mathrm{P}_{3} \mathrm{~N}_{9}$. The cyclic anions exist in a chair conformation (Fig. 5).
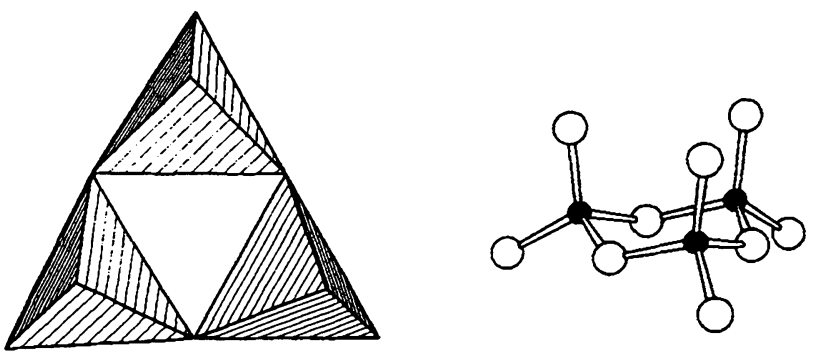

Fig. 5. Cyclutrisilicatc-like $\left[\mathrm{P}_{3} \mathrm{~N}_{9}\right]^{12-}$ ions (chair form) in $\mathrm{Li}_{12} \mathrm{P}_{3} \mathrm{~N}_{9}[52,53]$.

Since the molar ratio of phosphorus to nitrogen in $\mathrm{Li}_{5} \mathrm{P}_{2} \mathrm{~N}_{5}$ is $2: 5$, the analogy with the silicates leads us to expect either layer-type arrangements (silicate example: $\left.\mathrm{Ba}\left[\mathrm{Si}_{2} \mathrm{O}_{5}\right]\right)^{[57]}$ or double rings (example: $\left[\mathrm{Ni}\left(\mathrm{H}_{2} \mathrm{~N}\right.\right.$ $\left.\left.\left.\left(\mathrm{CH}_{2}\right)_{2} \mathrm{NH}_{2}\right)_{3}\right]_{3}\left[\mathrm{Si}_{6} \mathrm{O}_{15}\right] \cdot 26 \mathrm{H}_{2} \mathrm{O}^{[58]}\right)$ consisting of cornersharing $\mathrm{PN}_{4}$ tetrahedra. In fact this lithium phosphorus(v) nitride contains complex $\left[\mathrm{P}_{4} \mathrm{~N}_{10}\right]^{10-}$ ions, which are thus the first nitrido analogue of molecular phosphorus(v) oxide
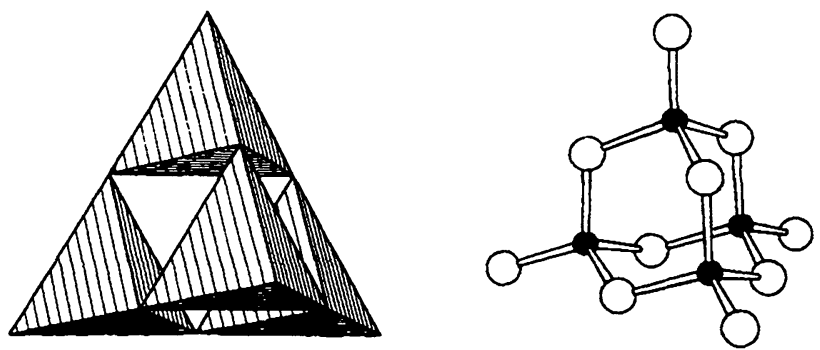

Fig. 6. Structure of the $\left[\mathrm{P}_{4} \mathrm{~N}_{101}\right]^{\mathrm{O}-}$ ion in $\mathrm{Li}_{10} \mathrm{P}_{4} \mathrm{~N}_{10}$. The complex anion has $T_{d}$ symmetry in the solid and a regular tetrahedral structure [54].
$\mathrm{P}_{4} \mathrm{O}_{10}$ (Fig. 6). ${ }^{[54]}$ As in molecular $\mathrm{P}_{4} \mathrm{O}_{10}$, and in agreement with the assumption of higher double bond or polar bond character, the bonds to the terminal atoms are clearly shorter than those to the bridging atoms $\left(\mathrm{P}_{4} \mathrm{O}_{10}: d\left(\mathrm{P}-\mathrm{O}_{\text {term }}\right)=141-\right.$ $151, d\left(\mathrm{P}-\mathrm{O}_{\mathrm{br}}\right)=153-160 \mathrm{pm} ;{ }^{[59]}\left[\mathrm{P}_{4} \mathrm{~N}_{10}\right]^{10-}: d\left(\mathrm{P}-\mathrm{N}_{\text {term }}\right)=$ $\left.158, d\left(\mathrm{P}-\mathrm{N}_{\mathrm{hr}}\right)=168 \mathrm{pm}^{[54]}\right)$.

There is a close relationship between the $\left[\mathrm{P}_{4} \mathrm{~N}_{10}\right]^{10-}$ cage and the cagelike double rings in the silicates. ${ }^{[58]}$ Thus both the $\left[\mathrm{P}_{4} \mathrm{~N}_{10}\right]^{10-}$ ions and the $\left[\mathrm{Si}_{6} \mathrm{O}_{15}\right]^{6-}$ double rings are composed of "dreier" ${ }^{[*]}$ rings. An $\left[\mathrm{Si}_{4} \mathrm{O}_{10}\right]^{4-}$ building unit isosteric with the $\left[\mathrm{P}_{4} \mathrm{~N}_{10}\right]^{10-}$ ion, which represents the smallest possible cage built up of corner-sharing $\mathrm{SiO}_{4}$ tetrahedra, has so far not been observed.

In the solid state, the complex anions in $2\left(\mathrm{Li}_{5} \mathrm{P}_{2} \mathrm{~N}_{5}\right)=$ $\mathrm{Li}_{10} \mathrm{P}_{4} \mathrm{~N}_{10}$ have ideal $T_{\mathrm{d}}$ symmetry; the ten nitrogen atoms form an almost undistorted section from cubic closest packing. In comparison with the situation in molecular phosphorus(v) oxide, a much more favorable packing of the complex building units is attained in the solid state; molecular $\mathrm{P}_{4} \mathrm{O}_{10}$. like urotropine, has a distorted body-centered structure (with respect to the center of gravity of the molecule), ${ }^{[60]}$ while the packing of the $\left[\mathrm{P}_{4} \mathrm{~N}_{10}\right]^{10-}$ units is derived from the cubic face-centered zinc blende-type structure. ${ }^{[54]}$ In the solid the neighboring $\left[\mathrm{P}_{4} \mathrm{~N}_{10}\right]^{10-}$ ions, which themselves have an almost completely regular tetrahedral structure, are arranged in a manner such that they face each other with their triangular surfaces parallel and rotated by $60^{\circ}$ (Fig. 7).
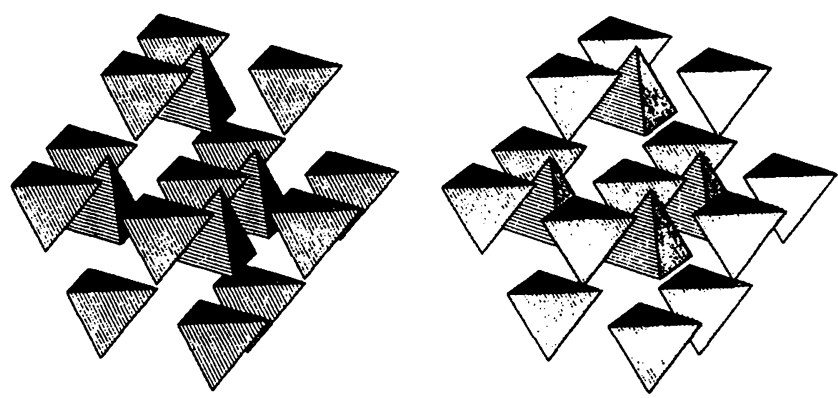

Fig. 7. Packing of the $\left[\mathrm{P}_{4} \mathrm{~N}_{10}\right]^{10-}$ ions in the solid state (stereoscopic representation)

The extension of this packing principle to a three-dimensional infinite solid leads to the formation of "free" layers, which extend in all directions in space because of the cubic symmetry of the crystal (Fig. 7): The lithium ions occupy these layers. Because of the topology of the complex anions in $\mathrm{Li}_{10} \mathrm{P}_{4} \mathrm{~N}_{10}$, the packing described for the solid does not permit the relatively high number of cations $\left(\mathrm{Li}^{+}:\left[\mathrm{P}_{4} \mathrm{~N}_{10}\right]^{10-}=10: 1\right)$ to be coordinated in a uniform manner by the nitrogen atoms. The $\mathrm{Li}^{+}$ions are coordinated either in a trigonal planar manner, tetrahedrally, or with a distorted octahedral nitrogen environment; the molar ratio of these arrangements is $6: 1: 2$. The remaining ten per cent of the lithium ions are distributed with disorder on a site with

[*] The term "dreier" ring was coined by Liebau [47] and is derived from the German word drei, which means three: however. a dreier ring is not a three-membered ring, but a six-membered ring comprising three tetrahedral centers and three electronegative atoms (cf. Figs. 5 and 6). Similar terms exist for rings comprising four, five, and six tetrahedral centers (and the corresponding number of electronegative atoms), namely "vierer", "fünfer", and "sechser" rings, respectively. 
higher multiplicity. Lattice-energy and point-potential calculations ${ }^{[61]}$ confirm that in the highly symmetric packing of the complex anions in $\mathrm{Li}_{10} \mathrm{P}_{4} \mathrm{~N}_{10}$ only a proportion of the cations can be accommodated in positions with deep potential wells (tetrahedrally and octahedrally coordinated $\mathrm{Li}^{+}$ ions). Only flat potential wells are available for the remaining cations, these leading in part to intrinsic disorder.

In all these lithium phosphorus(v) nitrides the $\mathrm{Li}-\mathrm{N}$ contact distances determined $d(\mathrm{Li}-\mathrm{N})=192-224 \mathrm{pm})$ are approximately equal to the sum of the ionic radii and increase as expected with the increasing coordination number of the cations. When the electronegativity differences $\Delta \chi$ between lithium and nitrogen $(\Delta \chi=2.0)$ and between phosphorus and nitrogen $(\Delta \chi=1.0)$ are taken into account, a simple Pauling-type estimate ${ }^{[62]}$ leads us to expect $\mathrm{P}-\mathrm{N}$ substructures with predominantly covalent bond character ( $78 \%$ covalent). The interactions between lithium and nitrogen should in contrast be predominantly $(63 \%)$ ionic. A systematic study of the lithium-phosphorus(v) nitrides is also of interest because the covalent and polarizable $\mathrm{P}-\mathrm{N}$ substructures in these compounds, in combination with their ionic $\mathrm{Li}-\mathrm{N}$ contacts, should lead to a considerable mobility of the $\mathrm{Li}^{+}$ions in the solid state, so that they could form a new class of ionic conductors. Impedance-spectroscopic measurements on $\mathrm{LiPN}_{2}$ and $\mathrm{Li}_{7} \mathrm{PN}_{4}{ }^{[63]}$ (Fig. 8) confirm this prediction. The solid state $\mathrm{Li}^{+}$ion conductivities determined are,

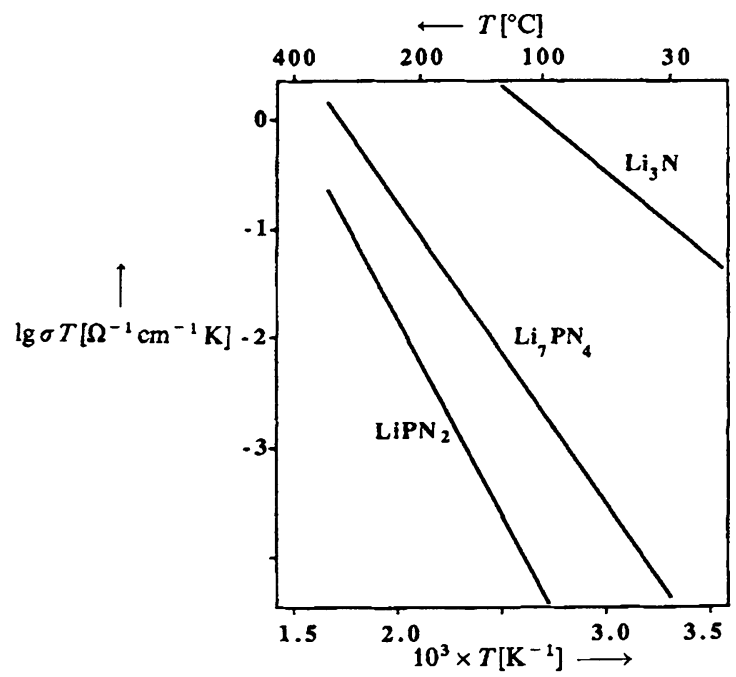

Fig. 8. Temperature dependence of the $\mathrm{Li}^{+}$ion conductivities in $\mathrm{Li}_{3} \mathrm{~N}, \mathrm{LiPN}_{2}$, and $\mathrm{Li}_{7} \mathrm{PN}_{4}[63]$.

however, lower than the extremely high conductivities of binary $\mathrm{Li}_{3} \mathrm{~N},{ }^{[50]}$ which arise on the one hand from an appreciable doping with hydrogen according to the formula $\mathrm{Li}_{3-x} \mathrm{H}_{x} \mathrm{~N}$, and on the other from the unusual crystal structure of lithium nitride. $\mathrm{Li}_{7} \mathrm{PN}_{4}$ has a higher conductivity and a lower activation energy than $\mathrm{LiPN}_{2}$ (Table 1). This difference between the two lithium phosphorus(v) nitrides can be understood on the basis of the crystal structures, the coordination of the $\mathrm{Li}^{+}$ions, and the number of charge carriers available in the solid state: In both $\mathrm{Li}_{7} \mathrm{PN}_{4}$ and $\mathrm{LiPN}_{2}$ all cations are coordinated tetrahedrally by nitrogen, the observed contact distances $\mathrm{Li}-\mathrm{N}$ being identical on average
Table 1. Specific $\mathrm{Li}^{+}$ion conductivities and activation energies of $\mathrm{Li}_{3} \mathrm{~N}$, $\mathrm{Li}_{7} \mathrm{PN}_{4}$, and $\mathrm{LiPN}_{2}$

\begin{tabular}{llll}
\hline & $\begin{array}{l}\sigma_{400 \mathrm{~K}} \\
{\left[\Omega^{-1} \mathrm{~cm}^{-1}\right]}\end{array}$ & $\begin{array}{l}E_{\mathrm{a}} \\
{\left[\mathrm{kJ} \mathrm{mol}^{-1}\right]}\end{array}$ & Ref. \\
\hline $\mathrm{Li}_{3} \mathrm{~N}$ & $4.0 \times 10^{-3}$ & 24 & {$[50]$} \\
$\mathrm{Li}_{7} \mathrm{PN}_{4}$ & $1.7 \times 10^{-3}$ & 47 & {$[51,63]$} \\
$\mathrm{LiPN}_{2}$ & $6.9 \times 10^{-7}$ & 59 & {$[55,63]$} \\
\hline
\end{tabular}

$\left(\mathrm{Li}_{7} \mathrm{PN}_{4}: 209 \mathrm{pm} ; \mathrm{LiPN}_{2}: 209 \mathrm{pm}\right) .^{[51,55]}$ The number of charge carriers available for ionic conductivity is, however, much higher in $\mathrm{Li}_{7} \mathrm{PN}_{4}$. Thus, $\mathrm{Li}_{7} \mathrm{PN}_{4}$, because of its composition, contains much more lithium; in addition the anti-fluorite crystal structure (identical with a defect $\mathrm{CsCl}$ type) has a large number of interstitial sites which are available for ionic conduction. $\mathrm{LiPN}_{2}$, in contrast, has a closely packed structure (chalcopyrite type, identical to a zinc blende modification). In this case no interstitial sites of comparable geometry are available. A diffusion of the $\mathrm{Li}^{+}$ions in the solid state is thus considerably hindered in $\mathrm{LiPN}_{2}$, which results in a higher activation energy and a conductivity lower than that of $\mathrm{Li}_{7} \mathrm{PN}_{4} \cdot{ }^{[63]}$

$\mathrm{Li}_{10} \mathrm{P}_{4} \mathrm{~N}_{10}$ contains structural features which lead us to expect a high mobility of the $\mathrm{Li}^{+}$ions in the solid: the symmetrical packing of the $\left[\mathrm{P}_{4} \mathrm{~N}_{10}\right]^{10-}$ ions leads to the formation of free layers which permeate the solid in all directions. The intrinsic disorder of the cations in this compound, the fact that the $\mathrm{Li}^{+}$ions most probably occupy broad, shallow potential wells, and the coordination modes of a fraction of the $\mathrm{Li}^{+}$ions which are particularly favorable for ionic conduction (trigonal planar) are all factors which would favor a high $\mathrm{Li}^{+}$ionic conductivity in the solid. ${ }^{[53,54]}$

The lithium phosphorus(v) nitrides discussed above contain either discrete complex $\mathrm{P}-\mathrm{N}$ anions $\left(\mathrm{Li}_{7} \mathrm{PN}_{4}, \mathrm{Li}_{12} \mathrm{P}_{3} \mathrm{~N}_{9}\right.$, $\mathrm{Li}_{10} \mathrm{P}_{4} \mathrm{~N}_{10}$ ) or a three-dimensional network of $\mathrm{PN}_{4}$ tetrahe$\operatorname{dra}\left(\mathrm{LiPN}_{2}\right)$. In the silicate family, the cyclosilicates are less stable than the corresponding chainlike compounds. Hard cations (e.g. $\mathrm{Li}^{+}, \mathrm{Mg}^{2+}$ ) increase this effect, while soft cations (e.g. $\mathrm{Ca}^{2+}, \mathrm{K}^{+}$) stabilize the rings. ${ }^{[47]}$ The replacement of the monovalent $\mathrm{Li}^{+}$ions by bivalent alkaline earth metal ions while the $P: N$ ratio is kept at $1: 3$ leads, in contrast to the observations made for the silicates, to a surprising result: A solid-state reaction between the corresponding amounts of the binary nitrides $\mathrm{Ca}_{3} \mathrm{~N}_{2}$ and $\mathrm{P}_{3} \mathrm{~N}_{5}$ [Eq. (12)] affords a ternary alkaline earth phosphorus(v) nitride of the composition $\mathrm{Ca}_{2} \mathrm{PN}_{3}$.

$$
2 \mathrm{Ca}_{3} \mathrm{~N}_{2}+\mathrm{P}_{3} \mathrm{~N}_{5} \frac{800^{\circ} \mathrm{C}, 4 \mathrm{~d}}{\text { W crucible, } \mathrm{N}_{2} \text { atm. }} 3 \mathrm{Ca}_{2} \mathrm{PN}_{3}
$$

While "dreier" rings are present in $\mathrm{Li}_{12}\left(\mathrm{PN}_{3}\right)_{3}=$ $\mathrm{Li}_{12} \mathrm{P}_{3} \mathrm{~N}_{9}$, the alkaline earth phosphorus(v) nitride contains infinite chains ${ }_{\infty}^{1}\left[\mathrm{PN}_{2} \mathrm{~N}_{2 / 2}^{4-}\right]$ of corner-sharing $\mathrm{PN}_{4}$ tetrahedra (Fig. 9). ${ }^{[64]}$ The "zweier" chain found here has an extreme stretching factor $f_{\mathrm{s}}=1.0$, as found, for example, in the chain silicate $\mathrm{CaMn}\left[\mathrm{Si}_{2} \mathrm{O}_{6}\right] \cdot{ }^{[47,65]}$ As well as the calcium compound, a magnesium phosphorus( $\mathrm{v}$ ) nitride $\mathrm{Mg}_{2} \mathrm{PN}_{3}$ is also known ${ }^{[66]}$ whose crystal structure is an ordered wurtzite variant. More recent studies ${ }^{[67]}$ indicate that this phosphorus(v) nitride also contains infinite "zweier" chains made up of corner-sharing $\mathrm{PN}_{4}$ tetrahedra. 


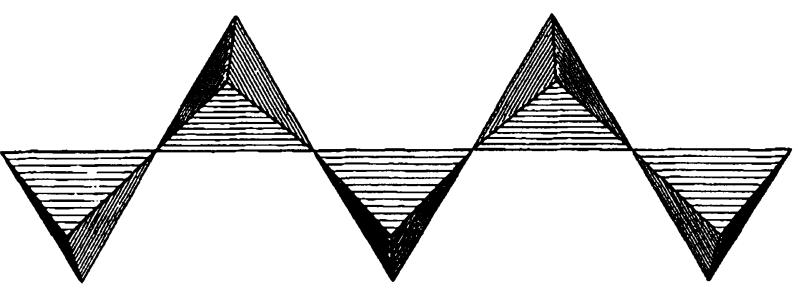

Fig. 9. Infinite "zweier" chains of corner-sharing $\mathrm{PN}_{4}$ tetrahedra in $\mathrm{Ca}_{2} \mathrm{PN}_{3}$ [64].

\subsection{Phosphorus(v) Nitride Imides and $\mathbf{P}-\mathbf{N}$ Sodalites}

The first intermediate in the ammonolysis of phosphorus pentachloride could in principle be the corresponding pentaamide $\mathrm{P}\left(\mathrm{NH}_{2}\right)_{5}$. In fact, however, condensation reactions occur when only a fraction of the chlorine atoms have been replaced by $\mathrm{NH}_{2}$ groups; these lead to the formation of oligocyclo- and polyphosphazenes. ${ }^{[68]}$ Product formation is influenced both by the reaction temperature and the ratio of $\mathrm{NH}_{3}$ to $\mathrm{PCl}_{5}$. so that either chlorine-rich compounds, such as $\left[\mathrm{NPClNH}_{2}\right]_{x}$, or completely substituted compounds, such as $\left[\mathrm{NP}\left(\mathrm{NH}_{2}\right)_{2}\right]_{x}$, are obtained. It was postulated that the final product of substitution and condensation reactions in the ammonolysis of $\mathrm{PCl}_{5}$ was a polymeric compound ${ }_{2}^{3}\left[\mathrm{PN}_{2 ; 2}\left(\mathrm{NH}_{2}\right)_{2 ; 2}\right] \triangleq \mathrm{HPN}_{2} \cdot{ }^{[69-71]}$ However, it is in fact found that the reaction of phosphorus pentachloride and ammonia leads to a vast number of different oligomeric and polymeric phosphazenes; thus, a homogeneous reaction product $\mathrm{HPN}_{2}$ is not formed. The compound $\mathrm{HPN}_{2}$ can, however, be obtained in a pure crystalline form from the heterogeneous ammonolysis of pure phosphorus(v) nitride under pressure [Eq. (13)]. A particularly useful procedure ${ }^{[72]}$ involves the in situ preparation of the ammonia required, starting from the corresponding amounts of ammonium chloride and magnesium nitride [Eq. (14)].

$$
\begin{aligned}
& \mathrm{P}_{3} \mathrm{~N}_{5}+\mathrm{NH}_{3} \stackrel{580 \mathrm{C} .14 \mathrm{~d}}{\longrightarrow} 3 \mathrm{HPN}_{2} \\
& \mathrm{Mg}_{3} \mathrm{~N}_{2}+6 \mathrm{NH}_{4} \mathrm{Cl} \stackrel{400^{\circ} \mathrm{C}}{\longrightarrow} 8 \mathrm{NH}_{3}+3 \mathrm{MgCl}_{2}
\end{aligned}
$$

Like LiPN 2 , phosphorus(v) nitride imide $\mathrm{HPN}_{2}$ has a network structure ${ }_{x}^{3}\left[\mathrm{PN}_{4 / 2}^{-}\right]$consisting of $\mathrm{PN}_{4}$ tetrahedra linked through all four vertices by corner-sharing. This structure can be derived from the isosteric $\beta$-cristobalite-type $(d(\mathrm{P}-$ $\left.\mathrm{N})=160 \mathrm{pm}, \Varangle \mathrm{P}-\mathrm{N}-\mathrm{P}=130^{\circ}{ }^{[721}\right)$; the hydrogen atoms are covalently bonded to one half of the nitrogen atoms of the $\mathrm{P}-\mathrm{N}$ skeleton. ${ }^{[72]}$

A second phosphorus(v) nitride imide, $\mathrm{HP}_{4} \mathrm{~N}_{7},{ }^{[73]}$ can be obtained by reacting the required amounts of $\mathrm{P}_{3} \mathrm{~N}_{5}$ and ammonium chloride in sealed quartz ampoules [Eq. (15)].

$4 \mathrm{P}_{3} \mathrm{~N}_{5}+\mathrm{NH}_{4} \mathrm{Cl} \stackrel{820^{\circ} \mathrm{C} .14 \mathrm{~d}}{\longrightarrow} 3 \mathrm{HP}_{4} \mathrm{~N}_{7}+\mathrm{HCl}$

Equation (16) shows that the removal of one molecule of ammonia from four formula units of $\mathrm{HPN}_{2}$ leads mathematically to the formation of $\mathrm{HP}_{4} \mathrm{~N}_{7}$. It is unfortunately not possible to carry out this reaction preparatively, since the

$4 \mathrm{HPN}_{2}-\overline{\mathrm{NH}_{3}}+\mathrm{HP}_{4} \mathrm{~N}_{7}$ thermal decomposition of $\mathrm{HPN}_{2}$ cannot be halted at the stage of $\mathrm{HP}_{4} \mathrm{~N}_{7}$.

There appears to be a close structural relationship between the two phosphorus(v) nitride imides. Thus, $\mathrm{HP}_{4} \mathrm{~N}_{7}$ can be regarded as a shear structure variant of $\mathrm{HPN}_{2}$. As shown above, the structure of $\mathrm{HP}_{4} \mathrm{~N}_{7}$ results from the elimination of one nitrogen atom (as $\mathrm{NH}_{3}$ ) from four formula units of $\mathrm{HPN}_{2}$; two of the remaining nitrogen atoms of the P-N skeleton then saturate the valences at the phosphorus atom. With respect to the $\beta$-cristobalite-like $\mathrm{P}-\mathrm{N}$ substructure ${ }_{x}^{3}\left[\mathrm{P}^{[4]} \mathrm{N}_{4 / 2}^{[2]-}\right]$ in $\mathrm{HPN}_{2}$, a fraction (two sevenths) of the nitrogen atoms in $\mathrm{HP}_{4} \mathrm{~N}_{7}$ must form three $\mathrm{P}-\mathrm{N}$ bonds according to the formula ${ }_{x}^{3}\left[\mathrm{P}_{4}^{[4]} \mathrm{N}_{5}^{[2]} \mathrm{N}_{2}^{[3]-}\right] \cdot{ }^{[73]}$

The ternary phosphorus(v) nitrides so far discussed that incorporate electropositive elements (hydrogen, alkali metals, or alkaline earth metals) mainly contain $\mathrm{P}-\mathrm{N}$ structural elements with isosteric analogues in the silicate family. It thus seemed appropriate to treat $\mathrm{Si}-\mathrm{O}$ compounds of particular interest, such as framework silicates and zeolites, as structural models for the preparation of new phosphorus( $(v)$ nitrides.

The importance of zeolites as catalysts, molecular sieves, adsorbents, and ion exchangers has increased considerably in recent years. The properties that render them so useful are based particularly on the characteristic topology of their tetrahedral skeletal structures, which have the general composition $\mathrm{TO}_{2}(\mathrm{~T}=\mathrm{Si}, \mathrm{Al}) \cdot{ }^{\left[{ }^{14]}\right.}$ By exchanging aluminum or silicon for other elements such as B, P, Ga, Ge, As, Sb, Ti, $\mathrm{Zr}, \mathrm{Hf}, \mathrm{Fe}, \mathrm{Cr}$, it proved possible to tailor the catalytic properties of zeolites in a manner favorable for certain applications. ${ }^{[74,75]}$ Substitution in the anion substructure of the framework, for example by replacing oxygen by other electronegative elements, has, in contrast, been almost completely neglected. It appeared to us that the preparation of nitrido zeolites should be particularly interesting in view of the possibility of obtaining desirable material properties (stability) and modifying the chemical properties of the zeolites (basicity).

The synthesis of a zeolite-like framework structure ${ }_{\infty}^{3}\left[\mathrm{PN}_{4 / 2}^{-}\right]$is possible ${ }^{[76]}$ when, for the in situ preparation of ammonia in the high-pressure ammonolysis of $\mathrm{P}_{3} \mathrm{~N}_{5}, \mathrm{Zn}_{3} \mathrm{~N}_{2}$ rather than $\mathrm{Mg}_{3} \mathrm{~N}_{2}$ is treated with ammonium chloride [Eq. (17)]. The reaction then proceeds quantitatively to afford $\mathrm{Zn}_{5} \mathrm{H}_{4}\left[\mathrm{P}_{12} \mathrm{~N}_{24}\right] \mathrm{Cl}_{2}$ [Eq. (18)]. Analogously to $\mathrm{HPN}_{2}$, a

$\mathrm{Zn}_{3} \mathrm{~N}_{2}+6 \mathrm{NH}_{4} \mathrm{Cl} \stackrel{400^{\circ} \mathrm{C}}{\longrightarrow} 8 \mathrm{NH}_{3}+3 \mathrm{ZnCl}_{2}$
$4 \mathrm{P}_{3} \mathrm{~N}_{5}+4 \mathrm{NH}_{3}+\mathrm{ZnCl}_{2} \stackrel{640^{\circ} \mathrm{C}}{\longrightarrow} \mathrm{Zn}_{5} \mathrm{H}_{4}\left[\mathrm{P}_{12} \mathrm{~N}_{24}\right] \mathrm{Cl}_{2}+8 \mathrm{HCl}$

phosphorus(v) nitride is formed, with a molar ratio $P: N=1: 2$, while at the same time zinc and chlorine are incorporated into the solid through gaseous $\mathrm{ZnCl}_{2}$, which is volatile under the experimental conditions. A complete exchange of the hydrogen atoms in the product obtained is possible in a subsequent reaction with additional $\mathrm{ZnCl}_{2}$ in which $\mathrm{HCl}$ is liberated [Eq. (19)].

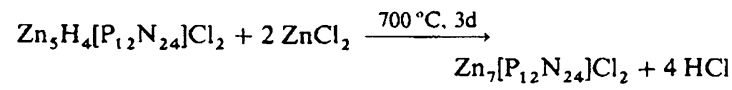


In $\mathrm{Zn}_{7}\left[\mathrm{P}_{12} \mathrm{~N}_{24}\right] \mathrm{Cl}_{2}$ phosphorus and nitrogen form a sodalite-like three-dimensional network ${ }_{x}^{3}\left[\mathrm{PN}_{4 ! 2}^{-}\right]$of $\mathrm{PN}_{4}$ tetrahedra which are linked through all four vertices by cornersharing. $\left(d(\mathrm{P}-\mathrm{N})=163.7 \mathrm{pm}, \Varangle \mathrm{P}-\mathrm{N}-\mathrm{P}=126^{\circ}\right.$; Fig. 10$)$.

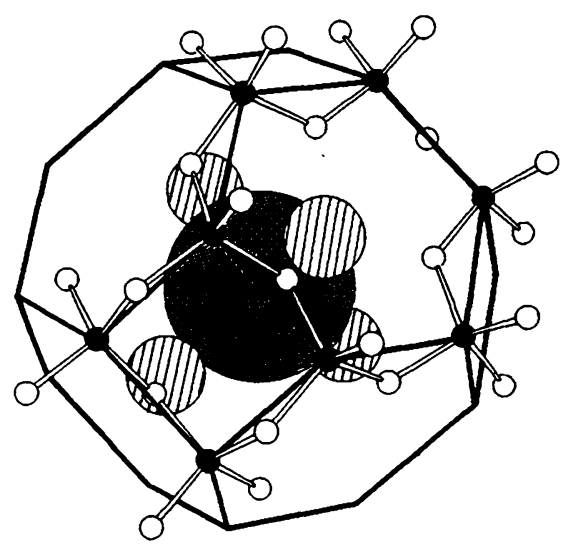

Fig. 10. Section of the crystal structure of $\mathrm{Zn}_{7}\left[\mathrm{P}_{12} \mathrm{~N}_{24}\right] \mathrm{Cl}_{2}$. The zeolite-like $\beta$-cage made up of condensed $\left[\mathrm{P}_{4} \mathrm{~N}_{4}\right]$ and $\left[\mathrm{P}_{6} \mathrm{~N}_{6}\right]$ rings is shown. $\mathrm{P}$ : black. $\mathrm{N}$ : white. $\mathrm{Cl}$ : gray, $\mathrm{Zn}$ : striped. The size of $\mathrm{Zn}^{2+}$ and $\mathrm{Cl}^{-}$corresponds to their respective ionic radii [76].

While in $\mathrm{HPN}_{2}$ and $\mathrm{LiPN}_{2}$, as in $\beta$-cristobalite, only threedimensionally bonded $\left[\mathrm{P}_{6} \mathrm{~N}_{6}\right]$ rings are found, the sodalitelike skeleton also contains $\left[\mathrm{P}_{4} \mathrm{~N}_{4}\right]$ rings. The two types of rings together form truncated octahedra ( $\beta$ cages), which are typical building units of sodalites and zeolites. Situated at the center of each $\beta$-cage is a chloride ion. in a tetrahedral environment of $\mathrm{Zn}^{2+}$ ions. Besides the $\mathrm{Zn}-\mathrm{Cl}$ contact $(260 \mathrm{pm})$, the metal cations have contact with three nitrogen atoms of the $\mathrm{P}-\mathrm{N}$ skeleton $(d(\mathrm{Zn}-\mathrm{N})=196 \mathrm{pm})$. According to the formula $\mathrm{Zn}_{7}\left[\mathrm{P}_{12} \mathrm{~N}_{24}\right] \mathrm{Cl}_{2}$, there is a statistical defect occupancy (occupancy factor $7 / 8$ ) at the $\mathrm{Zn}$ position. A fraction of the $\mathrm{Zn}^{2+}$ ions can be replaced by two protons each, which in turn are covalently bonded to nitrogen atoms of the $\mathrm{P}-\mathrm{N}$ skeleton. The $\mathrm{P}-\mathrm{N}$ sodalite has a phase width of $\mathrm{Zn}_{(7-x)} \mathrm{H}_{2 x}\left[\mathrm{P}_{12} \mathrm{~N}_{24}\right] \mathrm{Cl}_{2} \quad(0 \leq x \leq 2)$. By starting from a material with a lower metal content $\mathrm{Zn}_{6} \mathrm{H}_{2}\left[\mathrm{P}_{12} \mathrm{~N}_{24}\right] \mathrm{Cl}_{2}$, it is possible to prepare a chlorine-free phosphorus(v) nitride $\mathrm{Zn}\left(\mathrm{PN}_{2}\right)_{2}$ by elimination of $\mathrm{HCl}$ [Eq. (20)]; the structure of the product is highly distorted and it is no longer crystal-

$\mathrm{Zn}_{6} \mathrm{H}_{2}\left[\mathrm{P}_{12} \mathrm{~N}_{24}\right] \mathrm{Cl}_{2} \stackrel{800 \mathrm{C} .3 \mathrm{~d}}{\longrightarrow} 6 \mathrm{Zn}\left(\mathrm{PN}_{2}\right)_{2}+2 \mathrm{HCl}$

line. ${ }^{[73.77]}$ It is, however, probable that this compound possesses a three-dimensional network structure of cornersharing $\mathrm{PN}_{4}$ tetrahedra containing $\left[\mathrm{P}_{4} \mathrm{~N}_{4}\right]$ and $\left[\mathrm{P}_{6} \mathrm{~N}_{6}\right]$ rings. ${ }^{[73,77]}$

The synthetic method described previously is not suitable for the preparation of modified $\mathrm{P}-\mathrm{N}$ sodalites containing other metal cations, (e.g. alkaline earth metals, transition metals, lanthanides). On the one hand, it requires that the corresponding binary metal nitride $\mathrm{M}_{3} \mathrm{~N}_{2}$ be both existent and stable, while on the other, the metal chloride $\mathrm{MCl}_{2}$ formed in the reaction with $\mathrm{NH}_{4} \mathrm{Cl}$ must have a certain minimum volatility.

P-N Sodalites $\mathrm{M}_{5} \mathrm{H}_{4}\left[\mathrm{P}_{12} \mathrm{~N}_{24}\right] \mathrm{Cl}_{2}(\mathrm{M}=\mathrm{Zn}, \mathrm{Co}, \mathrm{Ni})$ can also be obtained remarkably easily by reacting correspond- ing amounts of the metal chloride $\mathrm{MCl}_{2}$, hexachlorocyclotriphosphazene $\left(\mathrm{PNCl}_{2}\right)_{3}$, and ammonium chloride [Eq. (21)]. This reaction is carried out in sealed ampoules,

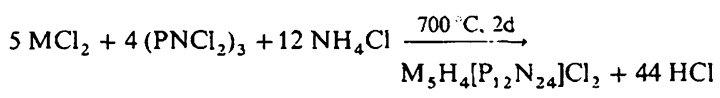

and the batch size is limited by the amount of $\mathrm{HCl}$ formed. An alternative procedure involves the use of a molecular phosphorus component in which the chlorine atoms are completely replaced by amino groups $\left[\left\{\mathrm{PN}\left(\mathrm{NH}_{2}\right)_{2}\right\}_{3}\right]$ [Eq. (22)]; in this case the product is the hydrogen-free $\mathrm{P}-\mathrm{N}$ sodalite $\mathrm{M}_{7}\left[\mathrm{P}_{12} \mathrm{~N}_{24}\right] \mathrm{Cl}_{2} \cdot{ }^{[77]}$

$7 \mathrm{MCl}_{2}+4\left(\mathrm{PN}\left(\mathrm{NH}_{2}\right)_{2}\right)_{3} \stackrel{700 \text { C. } 2 \mathrm{~d}}{\longrightarrow} \mathrm{M}_{7}\left[\mathrm{P}_{12} \mathrm{~N}_{24}\right] \mathrm{Cl}_{2}+12 \mathrm{NH}_{4} \mathrm{Cl}$ (22)

A particularly elegant method for the preparation of $\mathrm{P}-\mathrm{N}$ sodalites modified in various ways is the simple reaction between phosphorus(v) nitride imide $\mathrm{HPN}_{2}$ and the corresponding metal halide $\mathrm{MX}_{2}$ [Eq. (23)], which affords com-

$5 \mathrm{MX}_{2}+12 \mathrm{HPN}_{2} \stackrel{700 \mathrm{C} .2 \mathrm{~d}}{\longrightarrow} \mathrm{M}_{5} \mathrm{H}_{4}\left[\mathrm{P}_{12} \mathrm{~N}_{24}\right] \mathrm{X}_{2}+8 \mathrm{HX}$

pounds with a large number of different metal cations and halide ions (e.g. $\mathrm{M}=\mathrm{Mg}, \mathrm{Cr}, \mathrm{Mn}, \mathrm{Fe}, \mathrm{Co}, \mathrm{Ni}, \mathrm{Cu}, \mathrm{Zn}, \mathrm{Pb}$; $\mathrm{X}=\mathrm{Cl}, \mathrm{Br}) .^{[73,77]}$

By using the methods described above it has been possible to obtain a wide variety of $\mathrm{P}-\mathrm{N}$ sodalites. As well as divalent cations such as $\mathrm{Mg}^{2+}, \mathrm{Zn}^{2+}, \mathrm{Mn}^{2+}, \mathrm{Co}^{2+}, \mathrm{Ni}^{2+}, \mathrm{Cu}^{2+}$, $\mathrm{Pb}^{2+}$, trivalent cations such as $\mathrm{Cr}^{3+}, \mathrm{Fe}^{3+}$, and even monovalent cations such as $\mathrm{Cu}^{+}$can be incorporated. In all cases phase widths are observed in which a fraction of the metal ions can be replaced by the corresponding number of hydrogen atoms, which are then covalently bonded to nitrogen atoms of the P-N skeleton. ${ }^{173,77]}$

The $\mathrm{P}-\mathrm{N}$ sodalites exhibit remarkable properties: They are thermally stable up to about $800^{\circ} \mathrm{C}$ (in a nonoxidizing atmosphere) and are inert towards all common solvents as well as hot acids and alkalis. Of particular interest is the fact that, depending on the metal cation present, some $\mathrm{P}-\mathrm{N}$ sodalites are intensely colored (blue $(\mathrm{Co}, \mathrm{Ni})$, brown $(\mathrm{Fe})$, dark green $(\mathrm{Cr})$ ), which suggests that they may find a use as pigments.

\subsection{Silicon Phosphorus(v) Nitride $\mathrm{SiPN}_{3}$}

With respect to the development of new high-performance phosphorus(v) nitride ceramic materials it appears attractive to look at purely covalent ternary compounds containing both phosphorus and a second electropositive element, the latter being able to form a stable nitride which is a known ceramic material ( $\mathrm{BN}, \mathrm{AIN}, \mathrm{Si}_{3} \mathrm{~N}_{4}$ ). Earlier attempts to prepare ternary nitrides in the system $\mathrm{Si}-\mathrm{P}-\mathrm{N}$ or $\mathrm{B}-\mathrm{P}-\mathrm{N}$ starting from the binary nitrides were unsuccessful because of the low self-diffusion coefficient of these substances and the fact that the binary nitrides do not melt congruently.

Silicon phosphorus(v) nitride $\mathrm{SiPN}_{3}$ is, however, available from the molecular precursor $\mathbf{D}$ in which the required structural element $\equiv \mathrm{Si}-\mathrm{N}=\mathrm{P} \equiv$ is already preformed (Scheme 1). 
Compound $\mathbf{D}$ can be obtained in a three-step synthesis starting from bis(trimethylsilyl) azane ("hexamethyldisilazane") $\mathbf{A}$ and proceeding via the intermediates $\mathbf{B}$ and $\mathbf{C}$. Low temperature ammonolysis of $\mathbf{D}$, followed by removal of the ammonium chloride formed and pyrolysis in a stream of ammonia, leads to $\mathrm{SiPN}_{3} \cdot{ }^{[7]}$

$$
\begin{aligned}
& \left(\mathrm{CH}_{3}\right)_{3} \mathrm{Si}-\mathrm{NH}-\mathrm{Si}\left(\mathrm{CH}_{3}\right)_{3} \stackrel{\mathrm{SiCl}_{4}}{\longrightarrow} \mathrm{Cl}_{3} \mathrm{Si}-\mathrm{NH}-\mathrm{Si}\left(\mathrm{CH}_{3}\right)_{3} \stackrel{\mathrm{Cl}_{2},-40^{\circ} \mathrm{C}}{\longrightarrow} \\
& \Lambda \\
& \text { B }
\end{aligned}
$$

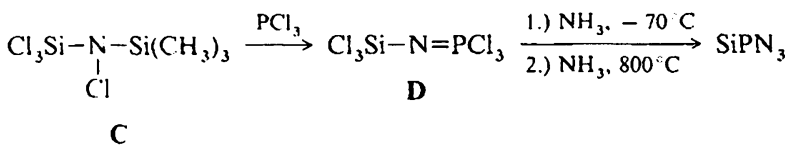

Scheme 1

Silicon phosphorus(v) nitride has a three-dimensional network structure of corner-sharing alternating $\mathrm{PN}_{4}$ and $\mathrm{SiN}_{4}$ tetrahedra. Analogous to the isosteric compounds $\mathrm{Si}_{2} \mathrm{~N}_{2} \mathrm{O}^{[79]}$ and $\mathrm{Si}_{2} \mathrm{~N}_{2} \mathrm{NH},{ }^{[80]}$ the crystal structure of $\mathrm{SiPN}_{3}$ is derived from a defect wurtzite modification. It contains two-dimensional infinitely linked layers of condensed sixmembered $\left[\mathrm{Si}_{3} \mathrm{~N}_{3}\right]$ rings in a boat form; half of the silicon atoms in the rings are replaced by phosphorus atoms. The ${ }_{x}^{2}\left[(\mathrm{Si} / \mathrm{P})_{3} \mathrm{~N}_{3}\right]$ layers, which are arranged parallel to each other in the crystal, are linked through bridging nitrogen atoms which saturate the remaining free valences at phosphorus and silicon (Fig. 11). ${ }^{[78]} \mathrm{SiPN}_{3}$ decomposes above about
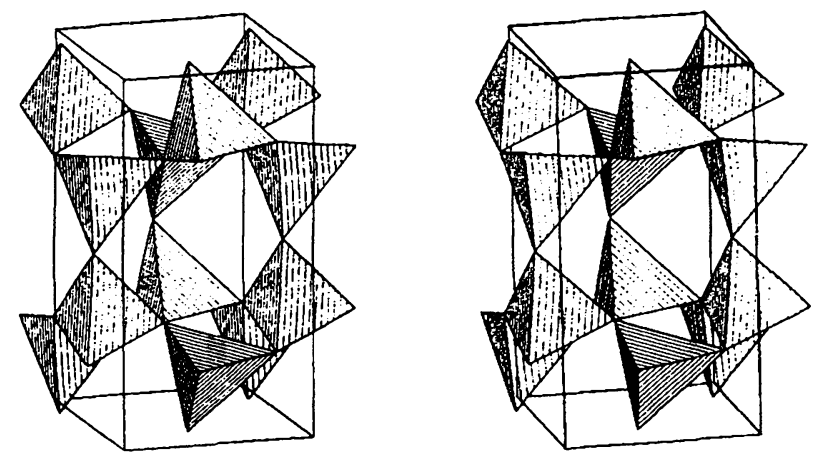

Fig. 11. ('rystal structure of $\mathrm{SiPN}_{3}$ (stereoscopic representation). The $\mathrm{SiN}_{4}$ and $\mathrm{PN}_{4}$ tetrahedra are shown as closed polyhedra [78].

$1000^{\circ} \mathrm{C}$ to give $\mathrm{Si}_{3} \mathrm{~N}_{4}$ and gaseous phosphorus $\left(\mathrm{P}_{4}\right)$, which acts as an oxygen scavenger. After $3 \mathrm{~h}$ at $1400^{\circ} \mathrm{C}$ the decomposition product is pure $\alpha-\mathrm{Si}_{3} \mathrm{~N}_{4}$, which acts as a nucleus for crystallization. Calcination of commercially available amorphous $\mathrm{Si}_{3} \mathrm{~N}_{4}$ by the addition of small amounts of $\mathrm{SiPN}_{3}$ gives pure crystalline $\mathrm{Si}_{3} \mathrm{~N}_{4}$ with a low oxygen content and a high content of $\alpha-\mathrm{Si}_{3} \mathrm{~N}_{4}$, which is preferred for sintering processes. ${ }^{[78]}$

\section{Ternary Boron Nitrides}

Very few ternary boron nitrides have so far been prepared. The dimorphic lithium boron nitride $\mathrm{Li}_{3} \mathrm{BN}_{2}{ }^{[81-83]}$ and the analogous sodium compound $\mathrm{Na}_{3} \mathrm{BN}_{2}{ }^{[84]}$ have been studied in detail and structurally characterized. Magnesium boron nitride $\mathrm{Mg}_{3} \mathrm{BN}_{3}{ }^{[85]}$ is also known; like $\mathrm{Li}_{3} \mathrm{BN}_{2}$ it has a catalytic effect on the conversion of hexagonal $(h-\mathrm{BN})$ to cubic boron nitride $(c-\mathrm{BN})$ under high-temperature/high-pressure conditions. ${ }^{[14]} \mathrm{A}$ more complex cerium boron nitride $\mathrm{Ce}_{15} \mathrm{~B}_{8} \mathrm{~N}_{25}$ has also been described. ${ }^{[86]}$ Besides $\mathrm{Na}_{3} \mathrm{BN}_{2}$. these ternary compounds are obtained by reacting the corresponding binary nitrides at temperatures between $800^{\circ} \mathrm{C}(\alpha$ $\left.\mathrm{Li}_{3} \mathrm{BN}_{2}\right)$ and $1480^{\circ} \mathrm{C}\left(\mathrm{Ce}_{15} \mathrm{~B}_{8} \mathrm{~N}_{25}\right)$. Since binary sodium nitride as a starting material for the preparation of $\mathrm{Na}_{3} \mathrm{BN}_{2}$ does not exist, a procedure for the preparation of this compound had to be devised in which $\mathrm{Na}_{3} \mathrm{~N}$ is a formal intermediate. The reaction of a mixture of elemental sodium and sodium azide has proved suitable [Eq. (24)]. Under the reaction conditions the otherwise unstable alkali metal nitride appears to react instantaneously to give the required product. ${ }^{[84]}$

$2 \mathrm{Na}+\mathrm{NaN}_{3}+\mathrm{BN} \underset{\text { Belt apparatus. } 4 \mathrm{GPa}}{1000^{\circ} \mathrm{C} .15 \mathrm{~min}} \rightarrow \mathrm{Na}_{3} \mathrm{BN}_{2}+\mathrm{N}_{2}$ (24)

The ternary boron nitrides so far characterized contain only "isolated" $\mathrm{B}-\mathrm{N}$ anions rather than condensed structural units. Thus, $\mathrm{Li}_{3} \mathrm{BN}_{2}$ and $\mathrm{Na}_{3} \mathrm{BN}_{2}$ are constructed of alkali metal cations and linear, symmetrical units $\mathrm{NBN}^{3-}$. The complex anion has 16 valence electrons and is thus isoelectronic with $\mathrm{CO}_{2}, \mathrm{NCO}^{-}, \mathrm{CNO}^{-}, \mathrm{N}_{2} \mathrm{O}, \mathrm{N}_{3}^{-}, \mathrm{CN}_{2}^{2-}$. $\mathrm{C}_{3}^{4-[87,88]}$ and $\mathrm{CBN}^{4-} \cdot{ }^{[89]}$ The relatively short $\mathrm{B}-\mathrm{N}$ bond length $\left(134 \mathrm{pm}^{[82-84]}\right)$ can be explained on the basis of either a considerable degree of double bond character or a polar bond; this result is in agreement with spectroscopic studies. ${ }^{[81]}$ The two dimorphic modifications of $\mathrm{Li}_{3} \mathrm{BN}_{2}$ differ in particular in a reorientation of the linear $\left[\mathrm{BN}_{2}\right]^{3-}$ ions: all the $\mathrm{Li}^{+}$ions in $\beta-\mathrm{Li}_{3} \mathrm{BN}_{2}$ (isostructural with $\mathrm{Na}_{3} \mathrm{BN}_{2}$ ) are almost tetrahedrally coordinated by nitrogen atoms, while in $x-\mathrm{Li}_{3} \mathrm{BN}_{2}$ they are in part linearly coordinated. ${ }^{[82.83]}$

Unexpectedly, $\mathrm{Mg}_{3} \mathrm{BN}_{3}$ also contains linear $\left[\mathrm{BN}_{2}\right]^{3-}$ ions. the structure in fact is $\left[\left(\mathrm{Mg}^{2+}\right)_{3}\left(\mathrm{BN}_{2}^{3-}\right)\left(\mathrm{N}^{3-}\right)\right]$; the "isolated" $\mathrm{N}^{3-}$ ions have no direct contact with boron atoms. ${ }^{[85]}$ A trigonal planar anion $\left[\mathrm{BN}_{3}\right]^{6-}(d(\mathrm{~B}-\mathrm{N})=$ $146 \mathrm{pm})$, isoelectronic with orthoborate $\left[\mathrm{BO}_{3}\right]^{3-}$, was found in $\mathrm{Ce}_{15} \mathrm{~B}_{8} \mathrm{~N}_{25}$; again "isolated" $\mathrm{N}^{3-}$ ions are also present, which are octahedrally surrounded by cerium atoms. ${ }^{[86]}$ The remarkably short Ce-Ce distances $(d(\mathrm{Ce}-\mathrm{Ce}) \geq 363 \mathrm{pm})$ indicate the presence of metal-metal bonds as well as the presence of a mixed-valency compound according to $\left[\left(\mathrm{Ce}^{4+}\right)_{6}\left(\mathrm{Ce}^{3+}\right)_{9}\left(\mathrm{BN}_{3}^{6-}\right)_{8}\left(\mathrm{~N}^{3-}\right)\right] \cdot{ }^{[86]}$

\section{Ternary Silicon Nitrides}

In spite of many attempts it has so far been possible to prepare only a few ternary silicon nitrides containing electropositive elements in a pure form and to characterize them both structurally and with respect to their properties. The isotypic compounds $\mathrm{MSiN}_{2}(\mathrm{M}=\mathrm{Be}, \mathrm{Mg}, \mathrm{Mn}, \mathrm{Zn})$ with the same valence electron concentration (VEC) of $4^{[90]}$ can be considered as ternary substitution variants of aluminum nitride (AIN).$^{[91-97]}$ Their preparation in pure form is possible by solid-state reactions of the corresponding binary nitrides [Eq. (25)] or, in the case of the manganese com- 
pound, by reacting $\mathrm{Si}_{3} \mathrm{~N}_{4}$ with elemental manganese in an ammonia atmosphere [Eq. (26)]. ${ }^{[94]}$

$$
\begin{aligned}
& \mathrm{Mg}_{3} \mathrm{~N}_{2}+\mathrm{Si}_{3} \mathrm{~N}_{4} \stackrel{1200}{\mathrm{C}} \mathrm{C} .3 \mathrm{MgSiN}_{2} \\
& 3 \mathrm{Mn}+\mathrm{Si}_{3} \mathrm{~N}_{4}+2 \mathrm{NH}_{3} \stackrel{1050 \mathrm{C}}{\rightarrow} 3 \mathrm{MnSiN}_{2}+3 \mathrm{H}_{2}
\end{aligned}
$$

In the solid state these compounds contain three-dimensional infinite network structures with $\mathrm{SiN}_{4}$ tetrahedra linked through all four vertices by corner-sharing, which forms condensed $\left[\mathrm{Si}_{6} \mathrm{~N}_{6}\right]$ twelve-membered rings $(d(\mathrm{Si}-\mathrm{N})=$ $174-180 \mathrm{pm}, \Varangle \mathrm{Si}-\mathrm{N}-\mathrm{Si}=122^{\circ}$ in $\mathrm{MgSiN}_{2}{ }^{[96]}$ ). Together with the metal cations these lead to a wurtzite-like structure.

$\mathrm{LiSi}_{2} \mathrm{~N}_{3}{ }^{[98]}$ and the structurally very similar silicon nitride imide $\mathrm{Si}_{2} \mathrm{~N}_{2} \mathrm{NH}^{1801}$ have defect wurtzite structures. The lithium compound can be obtained by reacting stoichiometric amounts of the binary nitrides $\left(100 \mathrm{~h}, 1000^{\circ} \mathrm{C}\right)$. Crystalline silicon nitride imide ${ }^{[80]}$ is obtained from silicon and ammonia under ammonothermal conditions by using potassium amide as a mineralizer [Eq. (27)].

$2 \mathrm{Si}+3 \mathrm{NH}_{3}-\frac{550: 600 \mathrm{C} \cdot 120 \mathrm{~h}}{6 \mathrm{kbar} \mathrm{NH}_{3}} \rightarrow \mathrm{Si}_{2} \mathrm{~N}_{2} \mathrm{NH}+4 \mathrm{H}_{2}$

Analogous to $\mathrm{Si}_{2} \mathrm{~N}_{2} \mathrm{O}$ and $\mathrm{SiPN}_{3}$ (see Section 3.3), $\mathrm{LiSi}_{2} \mathrm{~N}_{3}$ and $\mathrm{Si}_{2} \mathrm{~N}_{2} \mathrm{NH}$ consist of two-dimensional infinite, parallel layers of condensed $\left[\mathrm{Si}_{6} \mathrm{~N}_{6}\right]$ twelve-membered rings in a boat form, which are linked together by bridging nitrogen atoms $(d(\mathrm{Si}-\mathrm{N})=171-176 \mathrm{pm})$. In $\mathrm{Si}_{2} \mathrm{~N}_{2} \mathrm{NH}$ the hydrogen atoms are covalently bonded to the bridging nitrogen atoms, while in $\mathrm{LiSi}_{2} \mathrm{~N}_{3}$ the $\mathrm{Li}^{+}$ions occupy free tetrahedral sites in the defect wurtzite structure. Silicon nitride imide (like silicon diimide $\mathrm{Si}\left(\mathrm{NH}_{2}\right)_{2}$, which has so far only been obtained in an undefined amorphous form) is an intermediate in the industrial preparation of $\mathrm{Si}_{3} \mathrm{~N}_{4}$ from the ammonolysis of silicon tetrachloride. It decomposes above about $1050^{\circ} \mathrm{C}$ with elimination of ammonia to give $\mathrm{Si}_{3} \mathrm{~N}_{4} \cdot{ }^{[80]}$

Lanthanum silicon nitride $\mathrm{LaSi}_{3} \mathrm{~N}_{5}$ is obtained by reacting the binary nitrides under pressure $\left(1830^{\circ} \mathrm{C}, 270\right.$ bar $\left.\mathrm{N}_{2}\right)$; $^{[99]}$ the reaction of $\mathrm{Si}_{3} \mathrm{~N}_{4}$ with $\mathrm{La}_{2} \mathrm{O}_{3}\left(2000^{\circ} \mathrm{C}, 50\right.$ bar $\left.\mathrm{N}_{2}\right)$ also affords the compound as single crystals. ${ }^{[100]}$ As for all ternary silicon nitrides which have so far been characterized. $\mathrm{LaSi}_{3} \mathrm{~N}_{5}$ has a three-dimensional network structure with $\mathrm{SiN}_{4}$ tetrahedra linked through all four vertices by cornersharing. The solid contains "dreier", "vierer", "fünfer", and "sechser" (six-, eight-, ten-, and twelve-membered) rings with alternating silicon and nitrogen atoms. According to the molar ratio $\mathrm{Si}: \mathrm{N}=3: 5$, two-fifths of the nitrogen atoms are bonded to three silicon atoms $(d(\mathrm{Si}-\mathrm{N})=173-181 \mathrm{pm})$, while the remainder (three-fifths) have only two silicon atoms as directly bonded neighbors $(d(\mathrm{Si}-\mathrm{N})=162-$ $173 \mathrm{pm}$ ). Lanthanum is coordinated by a total of nine nitrogen atoms of the $\mathrm{Si}-\mathrm{N}$ substructure $(d(\mathrm{La}-\mathrm{N})=244$ $312 \mathrm{pm}) .^{[100]}$

Besides the compounds mentioned above, the existence of further ternary silicon nitrides such as $\mathrm{Li}_{2} \mathrm{SiN}_{2}, \mathrm{Li}_{5} \mathrm{SiN}_{3}$, and $\mathrm{Li}_{8} \mathrm{SiN}_{4}$ has been postulated, although it has so far not been possible to obtain exact structural data for these com- pounds or to determine their composition unequivocally. ${ }^{[10 !-104]}$ Studies of the quasibinary $\mathrm{Li}_{3} \mathrm{~N} / \mathrm{Si}_{3} \mathrm{~N}_{4}$ system have also produced some evidence for the existence of ternary lithium silicon nitrides with ionic conducting properties in the solid state. ${ }^{[05]} \mathrm{A}$ number of different phases was also identified in the $\mathrm{Be}_{3} \mathrm{~N}_{2} / \mathrm{Si}_{3} \mathrm{~N}_{4}$ system..$^{[106.107]}$

A number of germanium compounds isotypic with the corresponding silicon nitrides mentioned above are also known. ${ }^{[49.93 .94,97.101 .103 .108]}$

\section{Special Cases: Carbon and Sulfur}

In agreement with the quantification of the Van-ArkelKetelaar triangle as described by Allen, ${ }^{[109,110]}$ the nonmetals carbon, sulfur, or selenium (which are more electronegative than boron, silicon, or phosphorus) form binary nitrides which exhibit a clear preference for molecular structures. These binary nitrogen compounds in low oxidation states are often discrete molecules with homonuclear bonds (e.g. $\left.\left.(\mathrm{CN})_{2}, \mathrm{~S}_{4} \mathrm{~N}_{4}, \mathrm{~S}_{4} \mathrm{~N}_{2}, \mathrm{~S}_{5} \mathrm{~N}_{6}{ }^{[1}{ }^{1} 1\right]\right)$, though some polymeric compounds are also known (e.g. $(\mathrm{CN})_{x}$ and $\left.(\mathrm{SN})_{x}\right)$. Carbon and sulfur in the maximum oxidation state corresponding to their group number (IV and VI, respectively) have so far not provided any indication of the existence of the binary nitrides $\mathrm{C}_{3} \mathrm{~N}_{4}$ and $\mathrm{SN}_{2}$, respectively. Although ab initio calculations indicate that a hypothetical binary carbon nitride with a $\beta-\mathrm{Si}_{3} \mathrm{~N}_{4}$-like structure should have an unusual mechanical stability, ${ }^{[12.113]}$ no compound of the composition $\mathrm{C}_{3} \mathrm{~N}_{4}$ has until now been prepared in a pure defined form. ${ }^{[114-116]}$

The cyanamides can, however, formally be considered as ternary carbon(IV) nitrides $\left(\mathrm{M}_{2}^{1} \mathrm{CN}_{2}, \mathrm{M}=\mathrm{Li}, \mathrm{Na}, \mathrm{K}, \mathrm{Ag}, \mathrm{Tl}\right.$; $\mathrm{M}^{\mathrm{II}} \mathrm{CN}_{2}, \mathrm{M}^{\mathrm{II}}=\mathrm{Ca}, \mathrm{Sr}, \mathrm{Ba}, \mathrm{Zn}, \mathrm{Pb}$ ) which contain the linear anion $\mathrm{CN}_{2}^{2-}$ with 16 valence electrons. ${ }^{[17-120]}$ Lithium cyanamide can be prepared from lithium carbide and lithium nitride in molten lithium [Eq. (28)], though the separation of the product from lithium metal is preparatively difficult. ${ }^{[117.118]}$ Pure $\mathrm{Li}_{2} \mathrm{CN}_{2}$ can be obtained easily on a preparative scale from the reaction between lithium nitride and melamine in a molar ratio of $1: 2$ [Eq. (29)]. ${ }^{[121]}$

$\mathrm{Li}_{2} \mathrm{C}_{2}+4 \mathrm{Li}_{3} \mathrm{~N} \frac{530 \mathrm{C} .150 \mathrm{~h}}{\mathrm{Li} \mathrm{melt}} \rightarrow 2 \mathrm{Li}_{2} \mathrm{CN}_{2}+10 \mathrm{Li}$

$\left(\mathrm{NCNH}_{2}\right)_{3}+2 \mathrm{Li}_{3} \mathrm{~N} \stackrel{650 \mathrm{C}}{\longrightarrow} 3 \mathrm{Li}_{2} \mathrm{CN}_{2}+2 \mathrm{NH}_{3}$

Alkali metal hydrogen cyanamides $\left(\mathrm{NaHCN}_{2}\right.$, $\left.\mathrm{Na}_{4} \mathrm{H}_{2}\left(\mathrm{CN}_{2}\right)_{3}{ }^{[122,123]}\right)$ and crystalline cyanamide $\left(\mathrm{H}_{2} \mathrm{CN}_{2}{ }^{[124.125]}\right)$ have been prepared and structurally characterized. The reaction of dicyandiamide with cesium carbonate leads to cesium dicyanamide $\operatorname{Cs}\left[(\mathrm{CN})_{2} \mathrm{~N}\right]$, which in the solid state contains the bent pentaatomic anion $\mathrm{N} \equiv \mathrm{C}-\ddot{\mathrm{N}}-\mathrm{C} \equiv \mathrm{N}^{-}$. $^{[126]}$

In the case of sulfur(vI) no ternary or higher nitrides have so far been obtained. The only compound worthy of mention here is the sulfur(IV) compound $\mathrm{K}_{2} \mathrm{SN}_{2}$, which in the solid state contains the bent anion $\mathrm{SN}_{2}^{2-}$ isosteric with $\mathrm{SO}_{2} \cdot{ }^{[127]}$ Exact structural data are, however, not yet available for this compound. 


\section{Outlook and Future Prospects}

Numerous new publications, not only in the area of nonmetal nitrides, make it clear that nitride chemistry is still only in its infancy ${ }^{[128]}$ and that many fascinating results can be expected. As shown by the results of systematic studies on the phosphorus nitrides, nonmetal nitrides have the potential for the development of novel solids with interesting properties; these can be either related to the technically, industrially, and economically important sulfates, phosphates, and silicates, or may be completely novel. In contrast to oxygen, nitrogen affords an extension of the structural scope. since covalent bonds can be formed not only to two, but also to three or even four neighboring atoms. ${ }^{[129]}$ The synthesis of nitrido zeolites according to the structural model provided by the zeolites appears particularly attractive with respect to desirable material properties and the modification of known compounds. However, the extended structural possibilities offered by nitrogen lead us to expect that completely new types of structures should also be possible.

Regardless of the possible applications of such compounds as ceramic materials, ionic conductors, catalysts, or pigments, the systematic exploration of new nonmetal nitrides will close a large gap in the chemistry of the main group elements.

My grateful thanks are due to my co-workers Ute Berger, Verena Schultz-Coulon, Jan Lücke, and Martin Volkmann for their tenacity, their inspiration, and their enthusiasm during our pleasant and fruitful cooperation in the area of the phosphorus nitrides. I should like to thank the Deutsche Forschungsgemeinschaft, the Fonds der Chemischen Industrie, and the Ministerium für Wissenschaft und Forschung des Landes Nordrhein-Westfalen for their generous financial support. I am particularly indebted to Monika Schmitt for her understanding, her support, and for many stimulating suggestions.

Received: October 6, 1992 [A 907 IE] German version: Angew'. Chem. 1993, 105, 846

[1] C. Boberski, R. Hamminger, M. Peuckert, F. Aldinger, R. Dillinger, J. Heinrich, J. Huber, Angew: Chem. Adv. Mater. 1989, 101, 1592; Angew. Chem. Int. Ed. Engl. Adv. Mater. 1989, 28, 1560; Adv. Mater. 1989, $1,378$.

[2] G. Petzow, Ber. Bunsenges. Phys. Chem. 1989, 93, 1173.

[3] G. A. Slack, J. Phy's. Chem. Solids 1987, 48,641.

[4] A. F. Hollemann, E. Wiberg, Lehrbuch der Anorganischen Chemie, de Gruyter, Berlin, 1985, p. 139.

[5] G. H. Aylward, T. J. Findlay, Datensammlung Chemie, Verlag Chemie, Weinheim, 1975. p. $80 \mathrm{ff}$.

[6] A few reports of the preparation of tin nitride have been published, but in all cases the samples obtained could not be clearly characterized: a) R. S. Lima. P. H. Dionisio, W. H. Schreiner, Solid State Commun. 1991. 79, 395: b) R. G. Gordon, D. M. Hoffman, U. Riaz, Chem. Mater. 1992, 4, 68: c) L. Maya, Inorg. Chem. 1992, 31, 1958.

[7] W. Neubert, H. Pritzkow, H. P. Latscha, Angew. Chem. 1988, 100, 298; Angen: Chem. Int. Ed. Engl. 1988, 27, 287.

[8] R. T. Paine, C. K. Narula, Chem. Rey. 1990, 90, 73

[9] V. L. Vinogradov, A. V. Kostanovskii, High Temp. (Engl. Transl.) 1991, 29. 901 .

[10] a) A. Meller, Gmelin Handbuch der Anorganischen Chemie, Boron Compounds, tst Suppl. Vol. 2, Springer, Berlin, 1980, p. 1; b) ibid. 2nd Suppl. Vol. 1, 1983, p. 20; c) ibid. 3rd Suppl. Vol. 3, 1988, p. 1, and references therein.

[11] Yu. I. Krasnokutskii, S. N. Ganz, V. D. Parkhomenko, J. Appl. Chem. USSR (Engl. Transl.) 1976, 49, 307.

[12] S. Podsiadlo, J. Orzel, Pol. J. Chem. 1984, 58, 323.

[13] a) M. G. L. Mirabelli, L. G. Sneddon, Inorg. Chem. 1988, 27, 3271; b) D. Seyferth. W. S. Rees, Jr., Chem. Mater. 1991, 3, 1106; c) L. Maya, H. L. Richards, J. Am. Ceram. Soc. 1991, 74, 406.
[14] a) C. Hohlfeld, J. Mater. Sci. Lett. 1989, 8, 1082; b) M. Kagamida. H. Kanda. M. Akaishi. A. Nukui, T. Osawa, S. Yamaoka. J. Cristal Growth 1989, 94. 261 ; c) S. Nakano. H. Ikawa. O. Fukunaga. J. Am. C'erum. Soc. 1992, $75,240$.

[15] H. Lange, G. Wötting, G. Winter, Angew. Chem. 1991, 103, 1606; Ange'w: Chem. Int. Ed. Engl. 1991, 30, 1579.

[16] M. Billy, J.-C. Labbe, A. Selvaray, Mater. Res. Bull. 1983, 18, 921.

[17] R. Grün, Acta Crystallogr. Sect. B 1979, 35, 800.

[18] G. Schwier, G. Nietfeld, Werkstoffe und Konstruktion 1988, 2. 149.

[19] G. Schwier, G. Nietfeld, Sprechsaal, 1988, 121,174.

[20] G. Boden, S. Klemm, K. Quaritsch, Silikattechnik 1987, 38, 161.

[21] G. Boden. R. Irmisch, G. Himpel, T. Reetz, Sprechsaal 1989. 122, 224.

[22] Y. Tuohino, R. Laitinen, K. Torkell in Proc. 3rd Int. Conf. Powder Proc. Sci. (Eds.: G. L. Messing. S. Hirano, H. Hausner). American Ceramic Society, Westerville, USA, 1989, p. $337 \mathrm{ff}$.

[23] K. Komeya, H. Inoue. J. Mater. Sci. 1975, 10, 1243.

[24] H. Inoue. K. Komeya, A. Tsuge, J. Am. Ceram. Soc. 1982, 65, 205.

[25] M. Mori, H. Inoue, T. Chirai in Progress in Nitrogen Ceramics (Eds.: F. L. Riley), Nijhoff, Den Haag, 1983, p. $149 \mathrm{ff}$.

[26] T. Ishii. A. Sano, I. Imai in Silicon Nitride-1 (Eds.: S. Somiya. M. Mitomo, M. Yoshimura), Elsevier, London, 1990, p. $59 \mathrm{ff}$

[27] M. Blix, W. Wirbelauer, Ber. Dtsch. Chem. Ges. 1903, 36, 4220

[28] O. Glemser, P. Naumann, Z. Anorg. Allg. Chem. 1959, 298. 134

[29] K. S. Mazdiyasni, C. M. Cooke, J. Am. Ceram. Soc. 1973. 56, 628

[30] S. Prochazka, C. Greskovich. Am. Ceram. Soc. Bull. 1987, 57. 579.

[31] W. M. Shen (Union Carbide), EP-B 365295. 1989. Chem. Ahstr. 1990. 113, P11030n.

[32] Y. Kohtoku in Silicon Nitride-1 (Eds.: S. Somiya. M. Mitomo, M. Yoshimura), Elsevier, London, 1989, p. $71 \mathrm{ff}$.

[33] H. R. Allcock, Phosphorus-Nitrogen Compounds, Academic Press, New York, 1972, p. 288.

[34] D. E. C. Corbridge, Phosphorus - An Outline of its Chemistry. Biochemistry, and Technology, Elsevier, Amsterdam, 1990, p. 120.

[35] S. Vepřek. Z. Iqbal, J. Brunner, M. Schärli, Philosoph. Mag. B 1981, 43, 527.

[36] J. Cremer, H. Harnisch (Hoechst AG). DE-A 2608018, 1977; Chem. Abstr. 1978, 88, 9160b.

[37] J. Cremer, E. Joerchel, H. Harnisch (Hoechst AG), DE-A 2516915, 1976; Chem. Abstr. 1977, 86, 57574v.

[38] A. Stock, Ber. Dtsch. Chem. Ges. 1906, 39, 1967.

[39] A. Stock, B. Hoffman, Ber. Disch. Chem. Ges. 1903, 36. 314.

[40] A. M. Ficquelmont, C. R. Hebd. Seances Acad. Sci. 1935, 200, 1045.

[41] H. Jacobs, R. Kirchgässner. Z. Anorg. Allg. Chem. 1990, 581. 125.

[42] W. Schnick, Z. Naturforsch. B 1989, 44, 942.

[43] W. Schnick. J. Lücke, unpublished results.

[44] U. Wannagat, G. Bogedain, A. Schervan, H. C. Marsmann, D. J. Brauer, H. Bürger, F. Dörrenbach, G. Pawelke, C. Krüger, K. H. Claus, Z. Naturforsch. B 1991, 46, 931 .

[45] U. Wannagat, D. Burgdorf, H. Bürger, G. Pawelke, Z. Naturforsch. B 1991, 46, 1039

[46] H. R. Allcock, Chem. Rev. 1972, 72, 315.

[47] F. Liebau, Structural Chemistry of Silicates, Springer, Berlin, 1985.

[48] E. V. Borisov, E. E. Nifant'ev, Russ. Chem. Rev. (Engl. Transl.) 1977, 46. 842.

[49] N. E. Brese, M. O'Keeffe, Struct. Bonding (Berlin) 1992, 79, 307.

[50] A. Rabenau, Solid State Ionics 1982, 6, 277.

[51] W. Schnick. J. Lücke, J. Solid State Chem. 1990, 87, 101

[52] W. Schnick, Phosphorus Sulfur Silicon Relat. Elem., in press.

[53] W. Schnick, U. Berger, unpublished results.

[54] W. Schnick, U. Berger, Angew: Chem. 1991, 103, 857; Angew. Chem. Int Ed. Engl. 1991, 30,830.

[55] W. Schnick, J. Lücke, Z. Anorg. Allg. Chem. 1990, 588, 19.

[56] M. O’Keeffe, B. G. Hyde, Acta Crystallogr. Sect. B 1976, 32, 2923.

[57] K. F. Hesse, F. Liebau, Z. Kristallogr. 1980, 153. 33.

[58] Y. Smolin. Sov. Phys. Crystallogr. (Engl. Transl.) 1970, 15, 23.

[59] M. Jansen, B. Lüer, Z. Kristallogr. 1986, 177, 149.

[60] M. Jansen, M. Möbs, Z. Kristallogr. 1982, 159, 283.

[61] R. Nesper, (ETH-Zürich), personal communication.

[62] L. Pauling, The Nature of the Chemical Bond, Cornell University Press, Ithaca New York, 1960, p. $97 \mathrm{ff}$.

[63] W. Schnick, J. Lücke, Solid State lonics 1990, 38, 271.

[64] W. Schnick. V. Schultz-Coulon, Angew: Chem. 1993, 105, 308: Angern: Chem. Int. Ed. Engl. 1993, 32. 280.

[65] R. L. Freed, D. R. Peacor, Am. Mineral. 1967, 52, 709.

[66] R. Marchand, Y. Laurent, Mater. Res. Bull. 1982, 17, 399.

[67] W. Schnick, V. Schultz-Coulon, unpublished results.

[68] A. Schmidpeter, C. Weingand, F. Hafner-Roll, Z. Naturforsch. B 1969. 24, 799.

[69] H. Schiff, Justus Liebigs Ann. Chem. 1857, 101, 299.

[70] W. Couldridge, J. Chem. Soc. 1888, 53, 398.

[71] C. Gerhardt, Ann. Chim. Phys. 1846, 18, 188.

[72] W. Schnick, J. Lücke, Z. Anorg. Allg. Chem. 1992, 610, 121.

[73] J. Lücke, dissertation Universität Bonn, 1993.

[74] J. V. Smith, Chem. Rev. 1988, 88, 149. 
[7S] W. Hölderich, M. Hesse, F. Näumann, Angex: Chem. 1988, 100, 232; Angew: Chem. Int. Ed. Engl. 1988, 27, 226.

[76] W. Schnick, J. Lücke, Angew. Chem. 1992, 104, 208; Angew. Chem. Int. Ed. Engl. 1992, 31, 213.

[77] W. Schnick, J. Lücke, M. Volkmann, unpublished results.

[78] H. P. Baldus, W. Schnick, J. Lücke, U. Wannagat, G. Bogedain, Chem. Mater. in press.

(79) I. Idrestedt, C. Brosset, Acta Chem. Scand. 1964, 18, 1879.

[80] D. Peters, H. Jacobs, J. Less-Common Met. 1989, 146, 241.

[81] J. Goubeau, W. Anselment, Z. Anorg. Allg. Chem. 1961, 310, 248.

[82] H. Yamane, S. Kikkawa, H. Horiuchi, M. Koizumi, J. Solid State Chem. $1986,65,6$

[83] H. Yamane, S. Kikkawa, M. Koizumi, J. Solid State Chem. 1987, 71, 1.

[84] J. Evers, M. Münsterkötter, G. Oehlinger, K. Polborn, B. Sendlinger. J. Less-Common Met. 1990, 162, L17.

[85] H. Hiraguchi, H. Hashizume, O. Fukunaga, A. Takenaka, M. Sakata, J. Appl. Crystallogr. 1991, 24, 286

[86] J. Gaude, P. L'Haridon. J. Guyader, J. Lang, J. Solid State Chem. 1985, $59,143$.

[87] H. J. Meyer, Z. Anorg. Allg. Chem. 1991, 593, 185.

[88] W. Jeitschko, R. Pöttgen, Inorg. Chem. 1991, 30, 427.

[89] H. J. Meyer, Z. Anorg. Allg. Chem. 1991, 594, 113.

[90] E. Parthe, Crystal Chemistry of Tetrahedral Structures, Gordon and Breach, New York, 1964, p. $3 \mathrm{ff}$.

[91] P. Eckerlin, A. Rabenau, H. Nortmann, Z. Anorg. Allg. Chem. 1967, 353, 113.

[92] P. Eckerlin, Z. Anorg. Allg. Chem. 1967, 353, 225.

[93] J. David, Y. Laurent, J. Lang, Bull. Soc. Fr. Mineral. Cristallogr. 1970, 93, 153.

[94] M. Maunaye, R. Marchand, J. Guyader, Y. Laurent, J. Lang, Bull. Soc. Fr. Mineral. Cristallogr. 1971, 94, 561.

[95] M. Wintenberger, R. Marchand, M. Maunaye, Solid State Commun. $1977,21,733$.

[96] M. Wintenberger, F. Tcheou, J. David, J. Lang, Z. Naturforsch. B 1980 , $35,604$.

[97] T. Endo, Y. Sato, H. Takizawa, M. Shimada, J. Mater. Sci. Lett. 1992, 11, 424.

[98] J. David, Y. Laurent, J. P. Charlot, J. Lang, Bull. Soc. Fr. Mineral. Cristallogr. 1973, 96, 21

[99] C. E. Holcombe, L. Kovach, Am. Ceram. Soc. Bull. 1981, 60, 546.
[100] Z. Inoue, M. Mitomo, N. Ii, J. Mater. Sci. 1980, 15, 2915.

[101] R. Juza. H. H. Weber, E. Meyer-Simon, Z. Anorg. Allg. Chem. 1953, 273. 48.

[102] J. Lang, J. P. Charlot, Rev. Chim. Miner. 1970, 7, 121.

[103] J. David, J. P. Charlot, J. Lang, Rev. Chim. Miner. 1974, 11, 405.

[104] A. T. Dadd, P. Hubberstey, J. Chem. Soc. Dalton Trans. 1982. 2175.

[105] H. Yamane, S. Kikkawa, M. Koizumi. Solid State Ionics 1987, 25, 183.

[106] I. C. Huseby, H. L. Lukas, G. Petzow, J. Am. Ceram. Soc. 1975, 58, 377.

[107] T. M. Shaw, G. Thomas, J. Solid State Chem. 1980, 33, 63.

[108] R. Marchand, Y. Laurent. J. Guyader, P. L'Haridon, P. Verdier, J. Eur. Ceram. Soc. 1991, 8. 197.

[109] L. C. Allen, J. Am. Chem. Soc. 1989, 111, 9003.

[110] L. C. Allen, J. Am. Chem. Soc. 1992, 114, 1510.

[111] J. D. Woollins, Non-Metal Rings, Cages and Clusters, Wiley, New York, 1988, p. $96 \mathrm{ff}$.

[112] A. Y. Liu, M. L. Cohen, Science 1989, 245, 841.

[113] A. Y. Liu, M. L. Cohen, Phys. Rev. B. 1990, 41, 10727.

[114] H. X. Han, B. J. Feldman, Solid State Commun. 1988, 65, 921.

[115] L. Maya, L. A. Harris, J. Am. Ceram. Soc. 1990, 73, 1912.

[116] L. Maya, D. R. Cole. E. W. Hagaman, J. Am. Ceram. Soc. 1991, 74, 1686.

[117] M. G. Down, M. J. Haley, P. Hubberstey, R. J. Pulham, A. E. Thunder. J. Chem. Soc. Chem. Commun. 1978, 52.

[118] M. G. Down, M. J. Haley, P. Hubberstey, R. J. Pulham, A. E. Thunder, J. Chem. Soc. Dalton Trans. 1978, 1407.

[119] K. M. Adams, M. J. Cooper, M. J. Sole, Acta Crystallogr. 1964, 17. 1449.

[120] M. J. Cooper, Acta Crystallogr. 1964, 17, 1452.

[121] U. Berger, W. Schnick, unpublished results.

[122] M. G. Barker, A. Harper, P. Hubberstey, J. Chem. Res. Synop. 1978, 432.

[123] A. Harper, P. Hubberstey, J. Chem. Synop. 1989, 194.

[124] B. H. Torrie, J. Raman Spectrosc. 1992, 23, 465.

[125] B. H. Torrie, R. Von Dreele, A. C. Larson, Mol. Phys. 1992, 76, 405

[126] P. Starynowicz. Acta Crystallogr. Sect. C 1991, 47, 2198.

[127] M. Herberhold, W. Ehrenreich. Angew. Chem. 1982, 94, 637; Angew: Chem. Int. Ed. Engl. 1982, 21, 633; Angew: Chem. Suppl. 1982, 1346.

[128] Compare for example a) K. Dehnicke, J. Strähle, Angex: Chem. 1992 , 104, 978; Angex. Chem. Int. Ed. Engl. 1992, 31, 955; b) F. J. DiSalvo. Science 1990, 247, 649 .

[129] See for example the coordination and bonding situation in $\mathrm{SiO}_{2}$ and $\mathrm{Si}_{3} \mathrm{~N}_{4}, \mathrm{P}_{2} \mathrm{O}_{5}$ and $\mathrm{P}_{3} \mathrm{~N}_{5}$ or $\mathrm{B}_{2} \mathrm{O}_{3}$ and $\mathrm{BN}$. 